\title{
Invited review: Lying time and the welfare of dairy cows
}

\author{
Cassandra B. Tucker, ${ }^{1 *}$ ๑ Margit Bak Jensen, ${ }^{2}$ ๑ Anne Marie de Passillé, ${ }^{3}$ Laura Hänninen, ${ }^{4} \odot$ \\ and Jeffrey Rushen ${ }^{3}$ (D) \\ ${ }^{1}$ Center for Animal Welfare, Department of Animal Science, University of California, Davis 95616 \\ ${ }^{2}$ Department of Animal Science, Aarhus University, Foulum, 8830 Tjele, Denmark \\ ${ }^{3}$ Faculty of Land and Food Systems, University of British Columbia, Vancouver, BC, Canada, V6T 1 Z4 \\ ${ }^{4}$ Research Centre for Animal Welfare and Department of Production Animal Medicine, Faculty of Veterinary Medicine, University of Helsinki, \\ 00014 Finland
}

\section{ABSTRACT}

Adequate time lying down is often considered an important aspect of dairy cow welfare. We examine what is known about cows' motivation to lie down and the consequences for health and other indicators of biological function when this behavior is thwarted. We review the environmental and animal-based factors that affect lying time in the context of animal welfare. Our objective is to review the research into the time that dairy cows spend lying down and to critically examine the evidence for the link with animal welfare. Cows can be highly motivated to lie down. They show rebound lying behavior after periods of forced standing and will sacrifice other activities, such as feeding, to lie down for an adequate amount of time. They will work, by pushing levers or weighted gates, to lie down and show possible indicators of frustration when lying behavior is thwarted. Some evidence suggests that risk of lameness is increased in environments that provide unfavorable conditions for cows to lie down and where cows are forced to stand. Lameness itself can result in longer lying times, whereas mastitis reduces it. Cowbased factors such as reproductive status, age, and milk production influence lying time, but the welfare implications of these differences are unknown. Lower lying times are reported in pasture-based systems, dry lots, and bedded packs $(9 \mathrm{~h} / \mathrm{d})$ compared with tiestalls and freestalls (10 to $12 \mathrm{~h} / \mathrm{d}$ ) in cross-farm research. Unfavorable conditions, including too few lying stalls for the number of cows, hard or wet lying surfaces, inadequate bedding, stalls that are too small or poorly designed, heat, and rain all reduce lying time. Time constraints, such as feeding or milking, can influence lying time. However, more information is needed about

Received December 17, 2019

Accepted August 15, 2020.

*Corresponding author: cbtucker@ucdavis.edu the implications of mediating factors such as the effect of the standing surface (concrete, pasture, or other surfaces) and cow behavior while standing (e.g., being restrained, walking, grazing) to understand the effect of low lying times on animal welfare. Many factors contribute to the difficulty of finding a valid threshold for daily lying time to use in the assessment of animal welfare. Although higher lying times often correspond with cow comfort, and lower lying times are seen in unfavorable conditions, exceptions occur, namely when cows lie down for longer because of disease or when they spend more time standing because of estrus or parturition, or to engage in other behaviors. In conclusion, lying behavior is important to dairy cattle, but caution and a full understanding of the context and the character of the animals in question is needed before drawing firm conclusions about animal welfare from measures of lying time.

Key words: dairy cow, animal welfare, lying behavior, standing, motivation

\section{INTRODUCTION}

Growing interest in the welfare of dairy cattle (von Keyserlingk et al., 2013) has resulted in scientific research, animal welfare legislation, and nonregulatory animal welfare assurance schemes (Veissier et al., 2008; Hoenig and Coetzee, 2018). Earlier legislation and guidelines focused on "input-based" standards, which prescribed the particular housing or management methods that must be used. More recent on-farm animal welfare assessment protocols include animal-based welfare measures (Fraser, 2018), of which the European Welfare Quality program is the best known (Blokhuis et al., 2010). However, the costs of carrying out on-farm welfare assessments on commercial farms limit the time available to take animal-based measures, especially behavioral ones (Sørensen et al., 2007). Consequently, there is considerable interest in automatic recording of behaviors relevant to animal welfare in a time-efficient 
manner (European Food Safety Authority Panel on Animal Health and Welfare, 2012; Rushen et al., 2012).

The time cows spend lying down may reflect their welfare (European Food Safety Authority Panel on Animal Health and Welfare, 2009), and some animal welfare standards make recommendations about how much time cows should lie down (e.g., Canadian National Farm Animal Care Council, 2009; New Zealand Ministry for Primary Industries, 2019). Measuring this behavior has become easier through use of various automated loggers (e.g., Borchers et al., 2016), and measurement of lying behavior has become more common in research and in large-scale on-farm assessments of dairy welfare (e.g., O'Driscoll et al., 2008; Ito et al., 2009; Ledgerwood et al., 2010).

Our objective is to review the research into the time that dairy cows spend lying down and to critically examine the evidence for the link with animal welfare. We focus on adult cows and refer to other classes of cattle only when research on this group is lacking. Many aspects of the lying behavior of cattle may provide information about their welfare status - for example, the time spent in the process of lying down or getting up (e.g., Dippel et al., 2009; Plesch et al., 2010; Zambelis et al., 2019) and lying in various lying postures (e.g., Haley et al., 2001). However, to date, the time cows spend lying down represents the bulk of investigation in this area and is our focus. After an overview of the characteristics of lying behavior, we examine the direct evidence related to animal welfare: cows' motivation to lie down and the consequences for health and other indicators of biological function when this behavior is thwarted. We then review the environmental and animal-based factors that affect lying time and end by placing these in the context of the animal welfare.

\section{THE BEHAVIOR OF LYING DOWN}

Before diving into the animal welfare implications of lying behavior, we provide an overview of what is known about the amount of time cows engage in this behavior, how these patterns are structured within and between days, and how they get up and down as well as postures assumed while lying.

\section{Time Spent Lying Down}

On average, lactating cows lie down for 8 to $13 \mathrm{~h} / \mathrm{d}$, with the most commonly reported averages between 10 and $12 \mathrm{~h} / \mathrm{d}$ (Table 1). However, large differences exist among cows. For example, Figure 1 shows the distribution of daily lying time for 3,122 cows in tiestall and freestall herds in Canada and the United States (data combined from Charlton et al., 2014; Solano et al., 2016; Westin et al., 2016). The mean daily duration of time spent lying down is around $11 \mathrm{~h} / \mathrm{d}$ but varies among cows from less than $6 \mathrm{~h} / \mathrm{d}$ to more than $16 \mathrm{~h} / \mathrm{d}$ (Figure 1).

Table 1. Mean daily duration of lying time (and range) reported for lactating dairy cows in different types of housing systems

\begin{tabular}{|c|c|c|c|c|c|}
\hline Reference $^{1}$ & Location & Farms & Cows & Mean duration $(\mathrm{h} / \mathrm{d})$ & Range $(\mathrm{h} / \mathrm{d})$ \\
\hline \multicolumn{6}{|l|}{ Freestall with parlor } \\
\hline Ito et al. (2014) & US & 79 & 40/farm & 10.5 & \\
\hline Ito et al. (2009) & Canada & 43 & 2,033 & 11.0 & $9.5-12.9$ \\
\hline Thomsen et al. (2012) & Denmark & 39 & 1,233 & 10.7 & \\
\hline Wechsler et al. (2000) & Switzerland & 18 & 10/farm & 11.3 & \\
\hline Gomez and Cook (2010) & US & 16 & $\sim 13 /$ farm & 11.9 & \\
\hline Yunta et al. (2012) & Spain & 10 & 40/farm & 12.0 & \\
\hline Thorup et al.(2015) & Denmark & 4 & $200 /$ farm & 11.4 & \\
\hline Solano et al. (2016) & Canada & 141 & 40/farm & 10.6 & $8.2-13.2$ \\
\hline \multicolumn{6}{|l|}{ Freestall with $\mathrm{AMS}^{2}$} \\
\hline Westin et al. (2016) & Canada & 36 & $40 /$ farm & 11.3 & $9.7-13.5$ \\
\hline Deming et al. (2013) & Canada & 13 & 30/farm & 10.8 & \\
\hline Helmreich et al. (2014) & Switzerland & 4 & 138 & 10.6 & $9.4-11.5$ \\
\hline King et al. (2016) & Canada & 41 & 30/farm & 11.5 & $10.1-11.7$ \\
\hline \multicolumn{6}{|l|}{ Tiestall } \\
\hline Charlton et al. (2016) & Canada & 100 & $40 /$ farm & 12.5 & $10.0-15.0$ \\
\hline \multicolumn{6}{|l|}{ Dry lots } \\
\hline Steensels et al. (2012) & Israel & 3 & 210 & 8.9 & \\
\hline Tresoldi et al. (2017) & US & 10 & 10-15/farm & 9.0 & $7.4-10.6$ \\
\hline \multicolumn{6}{|l|}{ Deep-bedded pack } \\
\hline Endres and Barberg (2007) & US & 12 & 147 & 9.3 & $6.1-11.4$ \\
\hline \multicolumn{6}{|l|}{ Pasture } \\
\hline Sepúlveda-Varas et al. (2014) & Chile & 6 & 274 & 8.5 & \\
\hline Beggs et al. (2018) & Australia & 10 & 30/farm & 9.5 & \\
\hline
\end{tabular}

${ }^{1}$ Only includes studies that examined multiple farms.

${ }^{2} \mathrm{AMS}=$ automatic milking system 
A change in total lying time can come about as a result of a changed frequency of bouts, a change in bout duration, or both. The average bout frequency is typically between 9 to 11 bouts/d, with mean bout duration varying from 60 to $99 \mathrm{~min}$ (Ito et al., 2009; Thomsen et al., 2012; Charlton et al., 2014; Westin et al., 2016). However, again, there are large difference among cows in bout frequency and mean bout duration. For example, Westin et al. (2016) reported that daily bout frequency varied among cows from less than $5 / \mathrm{d}$ to more than $20 / \mathrm{d}$, and mean bout duration varied from less than $20 \mathrm{~min}$ to more than $150 \mathrm{~min}$. The duration of a single bout of lying down can also vary greatly for an individual cow, the shortest bouts being a few minutes, whereas the longest can be up to several hours (Tucker et al., 2009a; Silper et al., 2015), although evidence suggests that cattle are more willing to work for lying bouts that last at least $30 \mathrm{~min}$ (Jensen et al., 2005).

The most common measures of lying behavior include the total duration of time spent lying down within a period of time (usually a day), the frequency of bouts of lying down, and the bout duration (usually the mean bout duration), all of which can be automatically measured (Ledgerwood et al., 2010; Kok et al., 2015). Bout frequency and mean bout duration can be differentially affected by various factors: for example, cow parity is positively correlated with bout duration but negatively correlated with bout frequency (Vasseur et al., 2012), a hard lying surface results in longer bout duration but lower bout frequency and total lying time compared with softer surfaces (Rushen et al., 2007), and wet bedding results in fewer bouts but does not affect bout duration (Schütz et al., 2019). We recommend that all

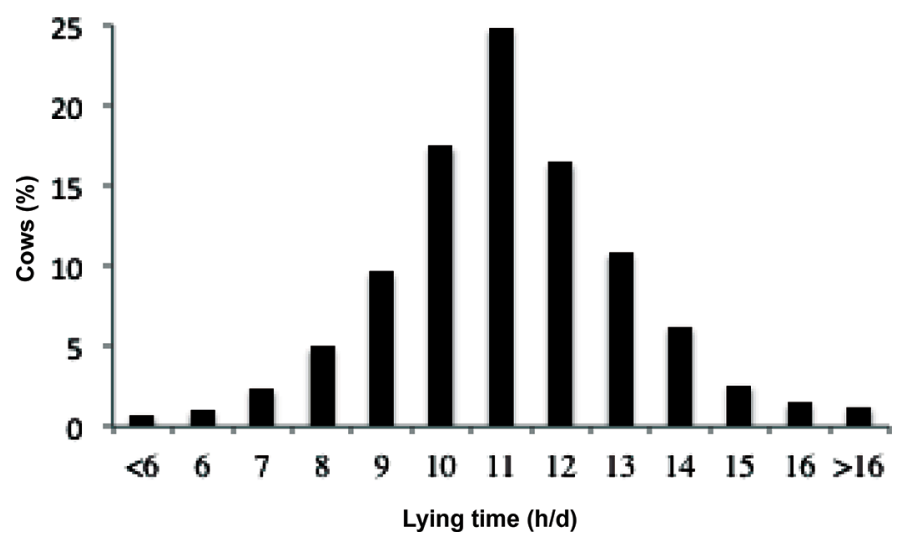

Figure 1. Percent distribution of daily lying times for 3,122 individual cows in tiestalls and freestalls, both with a conventional milking parlor and with an automated milking system, in Canada and the US. Based on averages for $4 \mathrm{~d}$. Data combined from 3 studies (Charlton et al., 2014; Solano et al., 2016; Westin et al., 2016).
3 measures, over $24 \mathrm{~h}$, should be taken to capture the lying behavior of cows.

\section{How Do Cows Lie Down?}

Cattle begin lying down by searching for an appropriate resting location (Krohn and Munksgaard, 1993). They then show intention movements, characterized by sniffing the surface and swinging the head from side to side close to the ground (Lidfors, 1989; Müller et al., 1989; Krohn and Munksgaard, 1993; Tucker and Weary, 2004; Bak et al., 2016). Keeping the head close to the surface, the animal bends one front leg, descends onto its carpal joints (one after the other) and places the hind leg of the intended lying side behind the opposite forelimb and underneath the body. The head is stretched forward and downward while the animal lowers the body to rest first on the brisket and then, after bending the hind legs, on the lower hind leg, thigh, and abdomen. During both standing up and lying down, both the horizontal and lateral movements of the animal's body can be sizable: Ceballos et al. (2004) estimated that a mature cow required $300 \mathrm{~cm}$ of longitudinal space and $109 \mathrm{~cm}$ of lateral space to complete the lying-down sequence.

While lying down, cattle assume a range of positions, which can be described by whether the animal is resting on the side or sternum, whether the front or back legs, or both, are folded under the body or extended, and whether or not the head is supported by the neck (e.g., Haley et al., 2001; Tucker et al., 2007b). These particular postures have been related to the phase of sleep in calves (Hänninen et al., 2008), but more studies are needed among adult cattle (Ternman et al., 2014). Lying postures may also relate to the fullness and size of the udder or to thermoregulatory responses, but we have little comprehensive data on this for lactating cows.

The way that cows lie down and the postures they adopt can explain some of the effects of housing on their lying time. For example, the fact that a large proportion of the weight is placed on the carpal joints when both standing up and lying down may explain some of the effects of carpal injury and stall flooring on lying time (e.g., Rushen et al., 2007), and space requirements may explain the effects of stall dimensions on lying behavior.

\section{When Do Cows Lie Down?}

Several studies have examined the times of day that cows lie down and have found clear evidence of diurnal rhythms. Although they do lie down during the 
day as well as during the night, the majority of their time lying down occurs during the latter (Winckler et al., 2015). However, this is less evident when cows are housed indoors, rather than at pasture (O'Connell et al., 1989; Ketelaar-de Lauwere et al., 1999).

\section{MOTIVATION}

Problems of animal welfare often occur when an animal is highly motivated to perform a particular behavior but is unable to do so because of the husbandry environment (Dawkins, 2004). Research into this aspect of behavioral deprivation has focused on the extent that motivation to perform the behavior increases when the animal is unable to perform the behavior so that compensatory behavior (a "rebound") is shown. One possibility (which is often assumed) is that cows are motivated to lie down for a certain amount of time per day. Another possibility is that cows attempt to limit the length of time they spend standing at a single time. These questions of motivation have been examined using several approaches.

\section{Evidence of Rebound or Compensatory Responses Associated with Lying Behavior}

The literature provides 3 primary forms of evidence about this. The first form examines how cows make tradeoffs between bouts of lying and standing behavior, of their own accord, and involves analysis of lying and standing bouts within a day. The second examines how lying behavior changes following thwarting, and the third quantified changes over days in response to unfavorable conditions or forced standing.

How cows make tradeoffs in the decision to stand up or lie down within a day can provide insight into their motivation for these behaviors. Good evidence exists that the probability of a cow standing up increases with the time spent lying down in a given bout (Jensen et al., 2005; Tucker et al., 2009a; Tolkamp et al., 2010). Similarly, we would expect the reverse effect: the probability of lying down should increase the longer the cow has been standing. Surprisingly, Tolkamp et al. (2010) found no relationship between the duration of the standing bout and the probability that the cow would lie down. However, we find several problems with this analysis. First, standing bouts over $4 \mathrm{~h}$ were rare, and standing bouts less than $4 \mathrm{~min}$ in length were not recorded. This may obscure any nonlinear relationships where both very long and very short standing bouts affected the motivation to lie down, for which some evidence does exist (e.g., Tucker et al., 2009a). In addition, the Tolkamp et al. (2010) analysis ignores the fact that some standing or lying bouts would have been affected by milking or feeding times. Consequently, we cannot conclude much about the motivation to lie down from this particular study, but the approach has value, in principle, without these methodological limitations.

Other research has examined how forced, prolonged standing affects cows' motivation to lie down afterward. When both dairy cows (Munksgaard and Simonsen, 1996) and young bulls (Munksgaard et al., 1999) were forced to stand for $7 \mathrm{~h}$ twice a day by physical restraint, they spent almost all of the remaining time $(93 \%$ and $95 \%)$ lying down. Cows forced to stand for $4 \mathrm{~h}$ spent more time lying down in the following $4 \mathrm{~h}$ (Norring and Valros, 2016) or $20 \mathrm{~h}$ (Bolinger et al., 1997) than those that were not. In addition, the latency to lie down can be short, 4 to $7 \mathrm{~min}$, after $4 \mathrm{~h}$ of forced standing (Krebs et al., 2011; Norring and Valros, 2016) and is over an hour sooner than cows that have not been standing for $4 \mathrm{~h}$ (Tucker et al., 2018). Quickly engaging in lying behavior (short latency to lie), once provided the opportunity, indicates that the cows are motivated to do so.

Cows have also been forced to stand, not by being physically restrained, but as a result of inappropriate surfaces or lack of space. These "environmentally imposed" standing periods also result in a rebound in lying behavior. For example, being kept temporarily on hard, wet, or muddy surfaces (Fisher et al., 2003; Schütz and Cox, 2014; Schütz et al., 2019) or rubber mats at high stocking densities (Schütz et al., 2015) resulted in a total reduction in time spent lying down in the 18 to $21 \mathrm{~h} / \mathrm{d}$ they were kept in these unfavorable conditions and a subsequent rebound lying behavior when released onto pasture each day. In contrast, in these studies, cows kept on comfortable surfaces, or with more space, spent the time on pasture grazing and showed little evidence of a rebound in lying behavior (quickly lying down upon release, spending more lying) during this time away from the experimental treatments. Others have also found that thwarting the ability to access a comfortable surface is followed by a compensatory increase in lying time, which could be substantial: Tucker et al. (2018) reported that cows that were unable to lie down for an average of about 14 consecutive hours spent close to $18 \mathrm{~h}$ lying down once they were able to access a deep-bedding area again. In light of these studies, we can conclude that the motivation to lie down is increased after 4 or more consecutive hours of forced standing.

The final line of evidence about motivation growing over time comes from experiments that exposed cows to unfavorable conditions or forced standing and quantified lying time over days and in comparison with 
controls kept in better conditions. Using this approach, Chen et al. (2017) found that heifers and cows reduced their lying time when exposed to very muddy conditions for 3 to $5 \mathrm{~h} / \mathrm{d}$. However after $2 \mathrm{~d}$ of exposure to mud, cattle spent between 8 and $10 \mathrm{~h} / \mathrm{d}$ lying, compared with a consistent $12+\mathrm{h} / \mathrm{d}$ over the same period on dry soil. Schütz and Cox (2014) also found that over a series of 4-d exposures to concrete, cows initially reduced their lying time dramatically (less than 6 out of $18 \mathrm{~h}$ ) but gradually began to spend more time lying (up to 8 out of $18 \mathrm{~h}$ ) over the $4 \mathrm{~d}$. Contemporary controls kept on softer wood chips maintain higher lying times, always more than 8 out of 18 h. Finally, Cooper et al. (2007) forced cows to stand for 2 or $4 \mathrm{~h}$ and then monitored whether they could recover this lost lying time over the following $40 \mathrm{~h}$; they found that cattle never fully recovered, compared with unrestricted controls. Taken together, these studies indicate that cows make some cumulative attempts to recover or maintain lying time, under unfavorable conditions or following forced standing.

\section{Tradeoffs Between Lying Down and Other Behaviors}

Studies have investigated cows' motivation to lie down by examining what they will forgo to lie down. The clear pattern is that cattle prioritize lying down over feeding, following deprivation of both or when time budgets are restricted in some way to make them choose one over the other. Metz (1985) found that, following $3 \mathrm{~h}$ of deprivation of both lying and feeding, cattle chose to lie down instead of eating when opportunities to engage in both behaviors were presented. Munksgaard et al. (2005) reduced the time available for lying down and feeding, as well as social activity. With $23 \mathrm{~h}$ available for all 3 activities, the dairy cows lay down for approximately $13 \mathrm{~h}$ per $24 \mathrm{~h}$, but when time available was reduced to either 12 or $15 \mathrm{~h}$, lying time was reduced to 8.5 and $9.7 \mathrm{~h}$. However, in both treatments the feeding time was reduced relatively more, and feed intake was reduced, to the extent that the cows lost weight (Munksgaard et al., 2005). Tucker et al. (2018) found a $32 \%$ reduction in feeding time due to a compensatory increase in lying time. Finally, several studies in New Zealand found that, when released onto pasture to eat for a limited number of hours each day, cows otherwise kept in unfavorable lying conditions opted to lie down during this time (Fisher et al., 2003; Schütz and Cox, 2014; Schütz et al., 2015, 2019), whereas contemporary controls that had more comfortable conditions for the nonpastured portion of the day did not make this sacrifice.

\section{Operant Conditioning and Consumer Demand Approaches}

Another way of assessing the importance of lying down to cows is to examine whether the opportunity to lie down can act as a reward in operant conditioning. This method can be extended by varying the "cost" that the cow must pay to lie down, an approach inspired by economic theory and often termed "consumer demand." The elasticity of a demand function is the percentage change in behavior as a function of the percentage change in price. If the behavior drops off steeply when the price is raised, then the behavior is evaluated to be less important than if the behavior had remained higher. This measures how sensitive to increasing cost a given behavior is; the less elastic, the more important the behavior (Jensen and Pedersen, 2008).

Jensen et al. (2004, 2005) housed pregnant heifers in tiestalls and prevented them from lying down twice daily, using a girth strap that forced the animals to remain standing. Following varying periods of deprivation, the heifers could press a panel to release the girth strap and have the opportunity to lie down. The heifers rapidly learned to do this, showing that the opportunity to lie down was reinforcing to the animals. The "cost" of lying down was varied by varying the number of times the animals had to press the panel to release the strap for each lying bout. In accordance with research showing that prolonged standing results in a rebound, pregnant heifers increased their work at a higher rate with increasing price following $6 \mathrm{~h}$ of forced standing versus following $3 \mathrm{~h}$ (Jensen et al., 2004), indicating a higher willingness to work following the longer forced standing. Heifers also increased their work at a higher rate with increasing price when they had access to longer lying bouts ( 20 vs. 30,50 , and $80 \mathrm{~min}$ ), indicating that, once lying, they want at least a certain amount of rest (Jensen et al., 2005). The results also identified the daily duration pregnant heifers want to lie down, as they increased their worked at increasing price to maintain approximately $13 \mathrm{~h}$ of lying overall (Jensen et al., 2005).

Another approach is to measure the cost the animal will pay for the largest meaningful reward (maximum price paid; Kirkden et al., 2003; Hovland et al., 2006). Cows have been asked about the maximum price they are willing to pay for access to a lying area by requiring them to push through a gate that required increasing force to open. Dairy cows maintained $13 \mathrm{~h}$ of lying until they either no longer pushed through the gate (on average, $36 \%$ of BW) or reached the maximum force of the apparatus (258 kgf; Tucker et al., 2018). This approach likely underestimates how much cows will work for a 
comfortable lying area, because when the gate became too heavy to open, cows would unsuccessfully try to open it, as many as 39 times in a single day (Tucker et al., 2018). These numerous attempts indicate that they had reached their physical limit, and not that their motivation had subsided.

\section{Possible Indicators of Frustration: Behavioral Changes When Lying Is Thwarted}

When cows are prevented from lying down, they often perform more intention movements (i.e., repeatedly sniffing the surface, often accompanied by swinging the head from side to side close to the surface or bending one front leg without lying down) as well as lying attempts - that is, placing one or both carpal joints on the surface, followed by standing up again (reviewed by Lidfors, 1989). Most of the experiments that have documented this response have examined unfavorable lying conditions such as little bedding (Tucker et al., 2009a) or hard surfaces (Haley et al., 2001), or these features of the lying surface combined with confinement (Müller et al., 1989; Krohn and Munksgaard, 1993), compared with cow behavior in environments that are known to be more comfortable.

Behavioral indicators of restlessness have been examined in experiments that have forced cattle to stand. These experiments report less feeding and more leaning (Norring and Valros, 2016) and more transitions between behaviors (Munksgaard and Simonsen, 1996; Munksgaard et al., 1999) when cows are prevented from lying down. Cows show more stepping and shifting weight from one limb to the other the longer they are forced to stand (Cooper et al., 2007; Chapinal et al., 2011; Krebs et al., 2011; Rajapaksha and Tucker, 2014, 2015; Rajapaksha et al., 2015; Schütz et al., 2018). Interpreting what this restlessness means in terms of animal welfare is complicated. On one hand, more restless behavior is shown by lame animals than by sound ones (Neveux et al., 2006; Chapinal and Tucker, 2012), which would imply that it indicates pain. However, it is also possible that restless behavior could function as a means to avoid fatigue through more blood circulation to the limbs. Further research is required to determine whether or not restlessness is associated with frustration.

\section{Motivation-Summary and Conclusions}

Overwhelming evidence confirms the importance of lying behavior for cows. Forcing cows to stand results in a higher motivation and compensatory lying ("rebound") when the opportunity arises. This can be sufficiently high as to result in a substantially reduced time spent feeding and, sometimes, reduced feed intake. The increase in motivation can occur when cows are prevented from lying down for as little as 3 to $4 \mathrm{~h}$, and cows show several behavioral changes that may indicate frustration when they are forced to stand.

\section{HEALTH AND BIOLOGICAL FUNCTION}

Problems of animal welfare occur when health is compromised (Dawkins, 2004). We review what is known about the implications of reduced time spent lying down in terms of health, as well as other aspects of biological function that may be affected, namely indicators of stress response, milk production, and the ability to sleep and ruminate.

\section{Increased Risk of Lameness and IIIness}

Several authors suggest that the risk of lameness is greater when lying areas are uncomfortable (Cook et al., 2007; Bell et al., 2009; Dippel et al., 2009; RouhaMülleder et al., 2009), and higher risk of lameness may be one of the most serious welfare consequences of reduced lying time. Some studies have shown an association between short lying time and the occurrence of lameness (Leonard et al., 1994; Galindo and Broom, 2000; Thomsen et al., 2012), and some aspects of stall design appear to be a risk factor for both lower lying time and more lameness (Bouffard et al., 2017). However, housing conditions that differ in the prevalence of lameness do not always differ in the time that the cows spend lying down (Cook et al., 2004; Ito et al., 2010). Such studies, however, are complicated by the possibility that, once cows become lame, they spend more time lying down. No studies have experimentally reduced lying time and examined consequent changes in lameness, so the best evidence that reduced lying time increases risk of lameness is limited to correlational studies that have found reduced lying time preceding the onset of lameness (Cook, 2020).

Of these, Leonard et al. (1996) found lower lying times in heifers 1 mo before claw lesions were measured, in populations where there was sufficient variation in lying time. Three (Chapinal et al., 2009; Proudfoot et al., 2010; Sepúlveda-Varas et al., 2014) of 4 more recent studies documented reduced time spent lying down before calving in cows that became lame or developed claw lesions after calving (10.6 vs. $12.2 \mathrm{~h} / \mathrm{d}, 10.1$ vs. $12.1 \mathrm{~h} / \mathrm{d}$, and 7.3 vs. $8.5 \mathrm{~h} / \mathrm{d}$, respectively). In contrast, Dippel et al. (2011) found no differences in lying behavior of freestall-housed dairy cows (all about $11 \mathrm{~h} / \mathrm{d}$ ) in the weeks before claw lesions were visible. Rather, these authors and Proudfoot et al. (2010) reported that spending more time standing partially in the stall, with 
the hind hooves in the alleyway, was associated with subsequent hoof health pathology.

Two other studies found that environmental conditions that led to cows becoming lame also led to reduced time spent lying down beforehand. An early study (Leach et al., 2005) noticed that feeding cows wet fermented grass silage resulted in cows spending less time lying down (11.1 vs. $13.0 \mathrm{~h} / \mathrm{d})$ before calving, and this increased the prevalence of claw lesions 18 to 24 mo after calving. Olmos et al. (2009) compared cows kept at pasture or housed indoors in a freestall barn. Cows at pasture had healthier claws than the cows housed indoors, and the difference was significant $85 \mathrm{~d}$ after calving. The cows at pasture also spent more time lying (12.2 vs. $8.1 \mathrm{~h} / \mathrm{d}) 33 \mathrm{~d}$ after calving and before the differences in claw lesion scores became apparent.

Changes in lying behavior may also increase the risk for other disease. For example, changes in post-milking standing time may affect the risk of mastitis if the cow does not remain standing for long enough to ensure that the teat canal closes before they come in contact with the lying surface. DeVries et al. (2010) found that cows kept in tiestalls had lower odds of getting a new udder infection if they lay down 40 to 60 min after milking compared with within the first 40 min after milking. However, in a study in a loose-housing barn with an automatic milking system, standing for long $(>2.5 \mathrm{~h})$ rather than short periods after milking increased the risk of infection (DeVries et al., 2012).

Considerable circumstantial evidence indicates that lying times less than $11 \mathrm{~h}$, especially around or before parturition, are associated with subsequent development of lameness and claw lesions. However, much of this evidence is longitudinal in nature, and, in some cases, lower lying times were confounded with other aspects of the animals' management (e.g., wet vs. dry fermented feed; pasture vs. freestall housing). Some of these confounding factors are also risk factors in their own right; for example, lameness tends to be lower when cows are kept on pasture (e.g., Hernandez-Mendo et al., 2007), further complicating our ability to draw conclusions about lying time, lameness, and causation.

\section{Physiological Indicators of the Stress Response}

Several studies have examined whether forcing cows to stand or keeping them in unfavorable conditions for lying down affects the hypothalamo-pituitary-adrenal (HPA) axis. Among studies, HPA axis responses vary. Inclement weather can result in more HPA activity and reduced lying time (Tucker et al., 2007b; Webster et al., 2008), but the causal relationships are unknown. Overstocking cows has been found to either increase cortisol concentrations (Friend et al., 1979) or have no effect (Krawczel et al., 2012a; Schütz et al., 2015). Similarly, cows kept in a concrete yard for $4 \mathrm{~d}$ had a shorter lying time $(7.0 \mathrm{~h} / \mathrm{d})$ and a higher fecal glucocorticoid metabolite concentration than cows kept on a wood chip pad with a much longer lying time (11.9 $\mathrm{h} / \mathrm{d}$ ). However, in the same experiment, cows kept on either a farm lane or in a small paddock had a severe reduction in lying time (5.7 vs. $6.9 \mathrm{~h} / \mathrm{d}$ ) but did not differ in fecal glucocorticoid metabolite concentration (Fisher et al., 2003). Studies that have forced cows to stand for 14.8 consecutive hours for $7 \mathrm{~d}$ report higher baseline cortisol compared with controls (Fisher et al., 2002), whereas others that forced cows to stand for 14 $\mathrm{h}$ (divided into two 7-h sessions) for $24 \mathrm{~d}$ found no differences in plasma cortisol (Munksgaard and Simonsen, 1996). A complication with the forced standing experimental model is that the method used to keep the cow upright - for example, an electrified girth strap (Fisher et al., 2002) - itself may be painful.

Forced standing and unfavorable lying conditions can also affect the reactivity of the HPA axis (Friend et al., 1979; Munksgaard and Simonsen, 1996; Fisher et al., 2002), but the response depends upon the duration of the treatment and the timing of blood sampling. For example, in a study with bulls, Munksgaard et al. (1999) found a decrease in cortisol response to CRF and ACTH following forced standing on d 3 after treatment, which was not apparent on d 22 and 49. The behavioral responses to forced standing were apparent on all $3 \mathrm{~d}$, showing that the change in HPA response was not due to general adaptation to the deprivation of lying down.

The hormonal responses to forced standing is not limited to the HPA axis. For example, Munksgaard and Løvendahl (1993) showed that forcing cows to stand for $14 \mathrm{~h} / \mathrm{d}$ (divided into two 7-h sessions) appeared to be associated with a reduction in growth hormone.

Taken together, the results suggest that forced standing and unfavorable lying conditions can induce physiological stress responses indicating reduced welfare. However, the changes are not simple or consistent. We do not yet know whether these changes result from the length of time that cows remained standing at one time, the reduction in overall daily lying time, or the methods used to prevent them from lying down. Nor do we yet know whether these effects occur following the shorter periods of forced standing thought to be more typical on commercial farms. We need to examine a broader range of hormonal systems and use a wider range of experimental models to manipulate when and how cows lie down, to better understand the physiological effects of lying and the consequences for the animals' welfare. 


\section{Changes in Milk Production}

Changes in milk production do not necessarily indicate a change in animal welfare. However, when this change is result of stress, such as those previously discussed, or illness or a reduction in feed intake, then concern about animal welfare is justified.

Reductions in lying time have been experimentally induced by unfavorable lying conditions such as overstocking (Krawczel et al., 2012a), manipulating the stall width (Tucker et al., 2004), or manipulating the comfort of stalls (Haley et al., 2000; Tucker et al., 2009c), and none of these found any change in the milk yield associated with these treatments. Thus, a direct and simple effect of altered lying time on milk yield seems unlikely (Cook, 2020); however, we note that the average lying times were all above $10 \mathrm{~h} / \mathrm{d}$ in these experiments. When cows had less time to both lie down and feed, they produced less milk, most likely due to a drop in feed intake (Munksgaard et al., 2005). Thus, the effects on milk production of preventing cows from lying down may depend on whether or not a resultant reduction in feed intake occurs as a result of competition for time spent lying down.

\section{Sleep}

An obvious biologically important behavior that occurs when cattle are lying down is sleep. Research in this area is affected and limited by our ability to quantify different types of sleep. Using electroencephalography (EEG), sleep can be subdivided into nonrapid eye movement (NREM) and rapid eye movement (REM). However, we lack a reliable noninvasive method to measure sleep in adult cows, as rumination causes disturbance to the EEG signal and makes it difficult to interpret the vigilance state while cows are chewing their cud (Hänninen et al., 2008; Ternman et al., 2012). However, to date, these methods do generate reliable estimates of REM sleep (Ruckebusch, 1972). In addition, NREM sleep and total time spent sleeping in adult cattle are possible to measure when the animals are not ruminating (Ternman et al., 2012, 2014, 2018, 2019; Kull et al., 2019), and the following results are limited by these constraints.

Cattle must lie down to have REM sleep, but they can have NREM sleep when standing if forced (Ruckebusch, 1974). Adult cattle sleep for considerably less time than they lie down: only $4 \mathrm{~h} / \mathrm{d}$, of which less than an hour is REM sleep (Ruckebusch, 1972; Ternman et al., 2018, 2019). The measurement method affects the amounts of NREM sleep recorded: studies using implanted electrodes reported $3 \mathrm{~h}$ of NREM sleep (Ruckebusch, 1972), whereas noninvasive techniques report only around $1 \mathrm{~h}$ (Ternman et al., 2018, 2019; Kull et al., 2019). The sleep cycle of adult dairy cows typically consists of 1 NREM bout lasting $5 \pm 3$ min and 1 REM bout lasting $3 \pm 1 \mathrm{~min}$, followed by the cow waking up (Ternman et al., 2012).

In one of the few sleep deprivation studies in cattle (Ruckebusch, 1974), cows were prevented from lying down for 14 to $22 \mathrm{~h} / \mathrm{d}$ for 2 mo. During periods of forced standing, cows increased their NREM sleep and markedly reduced REM sleep. Rebound effects were observed as a doubled amount of NREM and REM sleep during $4 \mathrm{~d}$ after deprivation, compared with beforehand (Ruckebusch, 1974). In more recent work, cows deprived for $24 \mathrm{~h}$ of either sleep or lying took between 2 and $4 \mathrm{~d}$ to recover their lying time, respectively (Kull et al., 2019). Unfortunately, very little is known about how changes in lying time affect time sleeping or the consequences of reduced sleep for cattle, and this clearly requires further research.

\section{Rumination}

The other main activity that cows engage in while lying down is rumination. Research is fairly consistent in finding that lactating cows ruminate, on average, between 7 and $9 \mathrm{~h} / \mathrm{d}$, for example, in freestalls with a milking parlor (Schirmann et al., 2012) or with an automatic milking system (Reith and Hoy, 2012), in tiestalls (Munksgaard and Simonsen, 1996), and at pasture (Kilgour, 2012). More rumination occurs at nighttime, at the time when cows are often lying down (Gregorini et al., 2012; Kilgour, 2012; Schirmann et al., 2012; Gregorini et al., 2013). When explicitly examining the relationship between rumination and lying time, some studies found no correlation (Schirmann et al., 2012), but others reported a negative correlation (Stone et al., 2017). Indeed, rumination time seems best explained by the physical and chemical composition of the diet and NDF intake (Beauchemin, 2018).

Although cows often ruminate while resting (e.g., Walker et al., 2008), when lying time is experimentally restricted, a larger proportion of the rumination then occurs while standing (Munksgaard and Simonsen, 1996). Similarly, Cooper et al. (2007) prevented cows lying down for a 2- or 4-h period and also observed that cows switched to ruminating while standing, but found that the duration of rumination was reduced. Three other studies have either forced cows to stand or overstocked the freestalls; none found significant changes in rumination time, although all report a numerical reduction in this behavior (Munksgaard and Simonsen, 1996; Krawczel et al., 2012a,b). Taken together, studies suggest that, although cows mainly ruminate while lying down, they can ruminate standing up, and when 
lying time is reduced rumination time is not reduced to nearly the same extent, if at all. However, we have no information as to whether the effectiveness of rumination is the same when cows are lying or standing.

\section{Health and Biological Function-Summary and Conclusions}

The risk of lameness and hoof lesions increases with reduced lying time, but this likely depends upon the surface on which the cows are standing. Reduced time lying down can result in some changes in the endocrine systems that often respond to stress, but the effects are complex and we do not yet know the consequences of this for the welfare of the animals. There is little evidence that reduced lying time reduces milk yield or rumination, or whether this is an animal welfare issue. Based on other species, reduced lying time may have further substantial effects on animal welfare if sleep is also reduced, and we need more evidence as to whether this occurs for cows.

\section{ENVIRONMENTAL INFLUENCES ON LYING TIME}

The lying time of cows is affected by many housing and management factors. Given the likelihood that forced reductions in lying time can have deleterious consequences for animal welfare, aspects of farm design and management that reduce lying time should be viewed with concern.

\section{Type of Housing System}

Cows in tiestall and freestall systems lie down, on average, between 10 and $12 \mathrm{~h} / \mathrm{d}$, whereas cows in bedded packs, dry lots, and pasture lie for about $9 \mathrm{~h} / \mathrm{d}$ (Table 1 ). However, the range in average lying times between individual farms that have the same type of housing system are large (e.g., 8.7 to $13.5 \mathrm{~h} / \mathrm{d}$ in freestalls and 6.1 to $12.1 \mathrm{~h} / \mathrm{d}$ at pasture; from Table 1 ). This suggests that measures of lying time on commercial farms depend greatly on management and the details of the housing system.

\section{Time Constraints Due to Feeding and Milking}

The extent that farm management affects the time that cows must spend in competing activities may be a considerable risk factor for reduced lying times. Feeding, milking, and waiting for access to milking can take a large amount of time (Charlton et al., 2014; Beauchemin, 2018), so that the time spent in these 2 activities will likely influence lying time. Social behavior, drinking, and grooming take less time $(<1 \mathrm{~h} / \mathrm{d}$; Dado and
Allen, 1994; Krohn, 1994; Huzzey et al., 2005; Cook et al., 2007; DeVries et al., 2007; Val-Laillet et al., 2009), and therefore we do not expect these activities to have a large effect on lying time. In addition, in some systems, cows are also restrained in headlocks while waiting for herd health checks or as part of breeding protocols, but few data are available about the variation in this practice, so although it may be a considerable time constraint for some cows, where they also have little choice in the matter, these are not well studied. Thus, we will focus on milking and feeding in our review of time constraints.

Friend et al. (1977) reported sizable negative correlations (ranging from -0.61 to -0.85 ) between the daily durations of feeding and lying down for cows in freestall systems, but small increases in feeding time $(<1 \mathrm{~h} / \mathrm{d})$ do not result in changes in lying time (Henriksen et al., 2019). As expected, larger increases in feeding time lead to a reduced time spent lying down. Munksgaard et al. (2006) reported that cows in tiestalls fed a low-energy diet spent $6.4 \mathrm{~h} / \mathrm{d}$ feeding and only $11.1 \mathrm{~h} / \mathrm{d}$ lying down, whereas cows fed a high-energy diet spent $4.8 \mathrm{~h} / \mathrm{d}$ feeding and $12.3 \mathrm{~h} / \mathrm{d}$ lying down. The similar size changes in feeding and lying times suggest a substitution of the two. Dohme-Meier et al. (2014) increased feeding time of cows from 6.6 to $8.8 \mathrm{~h} / \mathrm{d}$ by placing cows on pasture for 16 to $18.5 \mathrm{~h} / \mathrm{d}$, where they had to graze rather than eat TMR. The time spent lying down was reduced, but the change ( 10.3 to $9.7 \mathrm{~h} / \mathrm{d}$ ) was much smaller than for feeding time. This may reflect the relatively low time spent lying down in this study. In some cases, the relationships between lying and feeding time can be more complex: Crossley et al. (2017) increased competition for feed by increasing the number of cows per feed bin. Increased competition reduced both feeding times and lying times, probably because the cows were spending more time waiting to get access to the feeders. Waiting to feed or searching for free space at the feed bunk is an activity that can be time-consuming, but relatively little is known about this (Olofsson and Wiktorsson, 2001; Huzzey et al., 2006).

Changing when feed is delivered can also change cow lying time. When twice-daily feeding was delayed by $6 \mathrm{~h}$ relative to milking, DeVries and von Keyserlingk (2005) found that cows spent $12.5 \%$ more time feeding in total. Delayed feeding reduced the latency to lie down after milking by $20 \mathrm{~min}$, but it did not change the daily lying time.

No studies appear to have examined the relationship between average feeding time and lying time at the farm level. We examined the relationship across different research studies that report measures of both lying time and feeding time over $24 \mathrm{~h}$. Figure 2 shows the relationship between the average time cows spent lying 


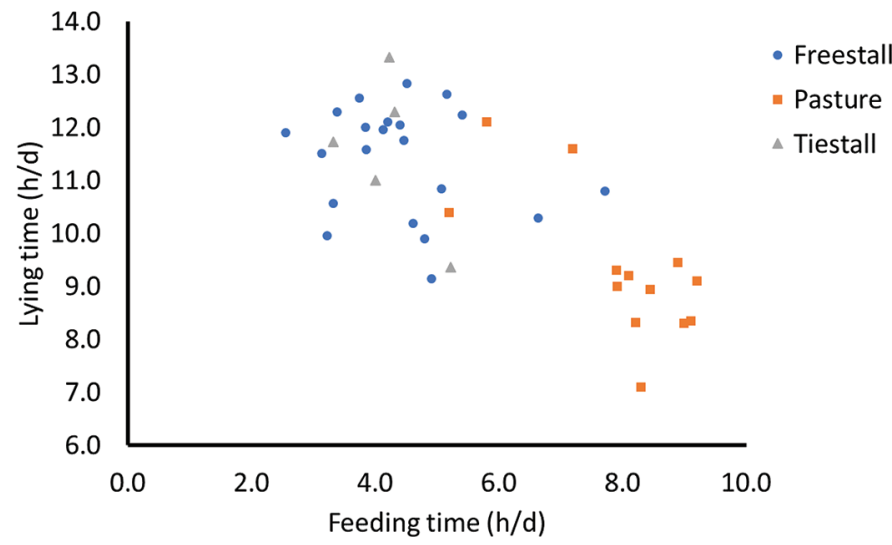

Figure 2. Relationship between time spent lying down and feeding for studies of cows in freestalls, in tiestalls, and at pasture (Wales et al., 2000a,b; Haley et al., 2001; Fregonesi and Leaver, 2002; González et al., 2003; Thorne et al., 2003; Fregonesi et al., 2004; DeVries and von Keyserlingk, 2005; Munksgaard et al., 2005, 2011; Kendall et al., 2006; Tucker et al., 2006, 2007a,b, 2008, 2009b; Cook et al., 2007; Rushen et al., 2007; Fisher et al., 2008; O’Driscoll et al., 2009; Collings et al., 2011; Schirmann et al., 2011; Siivonen et al., 2011a; Fogsgaard et al., 2012; Krawczel et al., 2012a,b; Matthews et al., 2012; Hart et al., 2013; Hetti Arachchige et al., 2013; Schütz et al., 2013; DohmeMeier et al., 2014; Kanjanapruthipong et al., 2015; Chen et al., 2016b; Løvendahl and Munksgaard, 2016; Wang et al., 2016; Crossley et al., 2017). To be included in this comparison, these 39 studies had to have measured lying and feeding time over $24 \mathrm{~h}$ simultaneously in the same animals.

down and the average time the cows spent feeding in both freestall and tiestall housing and at pasture.

It is apparent from Figure 2 that grazing time of cows at pasture is more variable among studies than is feeding time of cows in either freestall or tiestall housing, and that the lowest lying times found at pasture $(<9.3 \mathrm{~h} / \mathrm{d})$ occur when grazing times are longest $(>7.9 \mathrm{~h} / \mathrm{d})$. Where grazing times for cows at pasture are within the range found for feeding times in tiestall and freestall housing $(3.1$ to $7.7 \mathrm{~h} / \mathrm{d})$, then the times spent lying down (10.4 to $12.1 \mathrm{~h} / \mathrm{d})$ are also in the same range as cows in freestalls and tiestalls (10 to 12 $\mathrm{h} / \mathrm{d}$ ). In support of this interpretation, O'Driscoll et al. $(2010 a, 2019)$ report that lowering the quantity of pasture increased grazing time and reduced lying time after the morning milking. Similarly, when grazing and eating times overlap with values in tiestalls and freestalls, lying time is consistent, even if the overall feed availability spans a considerable range, between 8 and $16 \mathrm{~kg}$ of DM/d (Hetti Arachchige et al., 2013). Overall, these data suggest that the lower average lying times reported for cows at pasture compared with those in freestalls or tiestalls are associated with greater time spent grazing than feeding indoors.

Less research has examined the effect of milking time. Charlton et al. (2014) reported that the time that cows were away from the home pen for milking differed greatly between the 111 freestall farms visited, varying from less than 1 to more than $8 \mathrm{~h} / \mathrm{d}$. Although no overall correlation was detectable between time away for milking and the daily duration of lying time, no farm with a milking time greater than $3.7 \mathrm{~h} / \mathrm{d}$ had a lying time of $12 \mathrm{~h} / \mathrm{d}$ or greater. Up to a milking time of $3.3 \mathrm{~h} / \mathrm{d}$, no relationship occurred between milking and lying time. However, increased milking times above $3.3 \mathrm{~h} / \mathrm{d}$ were associated with a reduction in lying time, with the milking times accounting for $27 \%$ of the differences between farms in average lying time. Thus, the relationship between milking and lying time is likely to be nonlinear.

Research that has examined patterns of individual cows also provide insight into the effects of milking time. Gomez and Cook (2010) examined the association between milking times (time away from the pen for milking) and lying times for 205 lactating cows in 16 commercial freestall herds in the US but, unlike Charlton et al. (2014), reported results for individual cows. Milking time varied from 0.5 to $6.0 \mathrm{~h} / \mathrm{d}$, and an increase in milking time was associated with a 2- to 4-h/d decrease in lying time. In contrast, cows early or late in the milking order within 10 herds in Australia differed in the amount of time away from the paddock (1.4 vs. $4.5 \mathrm{~h} / \mathrm{d}$, on average), but every hour away reduced lying time by only $14 \mathrm{~min} / \mathrm{d}$ (Beggs et al., 2018). Time away for milking explained only $14 \%$ of the variation in lying time in this study (Beggs et al., 2018). These mixed results highlight the complexity of these interactions, and other factors, such as what the cows do while standing, likely also play a role.

Experiments that either remove or add a milking also have the potential to inform how milking influences lying time. Some experiments find that eliminating a milking - for example, from twice to once a day at peak lactation - tends to result in higher lying times at pasture (1×: 9.8 , vs. $2 \times: 8.3 \mathrm{~h} / \mathrm{d}$; Tucker et al., 2007a), but others find that this transition has no consistent effect (O'Driscoll et al., 2010b, 2011). Interpretation of research that reduces milking frequency is also confounded by complications associated with changes in udder fill. When a milking is added, Hart et al. (2013) reported that cows milked 2 or $3 \times$ daily spent 11.5 to $11.7 \mathrm{~h}$ lying down, regardless of this management difference. These authors report that the additional third milking took only $15 \mathrm{~min} / \mathrm{d}$, so perhaps it is not unexpected that the effect on the animals' time budget was minimal.

The animal welfare implications of these behavioral tradeoffs are dependent on (1) the degree of choice the cow has and (2) the biological implications of reduced lying time. If cows are willing to spend more time grazing and relatively less time lying, and their need to 
perform both behaviors is fulfilled, then there is little cause for concern. However, if cows would rather spend more time lying, if given the opportunity, if they experience hunger, or evidence indicates that their biological function is impaired (e.g., weight loss, greater risk for disease), then the lower lying times are problematic. Milking times that result in lower lying times are more problematic than tradeoffs with feeding, given that cows often do not have much choice in the matter and are standing on concrete during all (freestall, dry lots, bedded packs) or part of this time (pasture). There are likely detrimental health implications of the additional time spent standing on concrete, regardless of the reason (Cook, 2020).

\section{Stall Stocking Density}

One factor that could affect the lying time of cows is the availability of a lying area (Krawczel and Lee, 2019). One controversial practice in freestall housing is overstocking, where more cows than lying stalls are present: some animal welfare standards for dairy cattle use a cutoff value of 1.2 cows per stall (National Farm Animal Care Council, 2009), and others require enough stalls for all individuals (OIE, 2019). In several studies, the stocking density of lactating cows has been manipulated experimentally in small groups, either by preventing access to some stalls or by increasing the number of cows and keeping the number of stalls constant; the methods used achieve a similar outcome in these conditions (Krawczel et al., 2012b). These studies show that with increasing stocking density (cows per lying stall), the total lying time decreases, although the level of the effect varies from study to study (mean values from available experimental studies on lactating cows are summarized in Figure 3).

All studies find that average lying time within the herd is reduced when stocking density is above 1.2 cows per lying stall, but in the studies that have looked at stocking densities between 1.0 and 1.2 cows per stall, conflicting results are reported: most report no reduction in lying time (Friend et al., 1977; Hill et al., 2009; Krawczel et al., 2012a), but others (Fregonesi et al., 2007a) do find one. However, some studies have found that lying time continues to increase with understocking, or less than 1.0 cow per lying stall (Telezhenko et al., 2012; Lobeck-Luchterhand et al., 2015; Winckler et al., 2015; Cortés Fernández de Arcipreste et al., 2018), so we find reasons to be skeptical of the assumption that stocking density can be increased to 1.2 cows per stall without negative effects on lying time.

We note several caveats in interpreting the results of these studies. First, the average lying times of the entire herd may not give the whole picture of the effects of overstocking: lying times of subordinate cows may be most reduced, because they are more likely to be displaced from stalls (Friend et al., 1977; Fregonesi et al., 2007a). Friend et al. (1977) reported more variability in lying time as stocking density increased $(\geq 1.2)$ and found a positive correlation between lying time and social dominance. Furthermore, cows were displaced from stalls more at high stocking densities. It may also be misleading to look only at total lying time over 24 h. For example, Hill et al. (2009) reported that lying at certain times of the day was reduced by overstocking, even if average daily lying times was not affected. Similarly, Winckler et al. (2015) found that cows that were less successful in gaining access to stalls used them more during the day, compared with more successful cows, indicating that they shifted how they used this resource. Although the direct effect of stocking density on sleep is not known, a greater proportion of cattle sleep occurs at night (Ruckebusch, 1975; Ternman et al., 2014, 2018, 2019) and could be disproportionally affected if lying time at this time was displaced. Finally, the way that stall stocking density is manipulated may also have an effect. Most researchers increased stocking density by blocking access to certain stalls, which means the results are not affected by group size or by changes in stocking rate at the feed bunk. However, in reality, higher stocking density on commercial farms

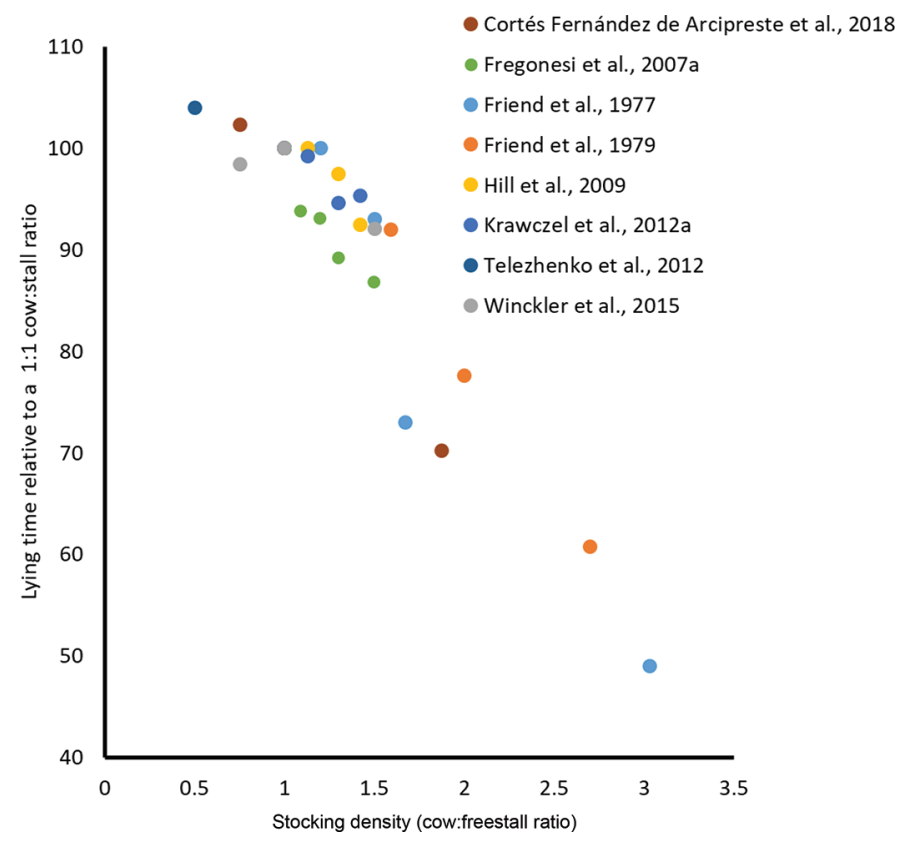

Figure 3. Relationship between stocking density (number of cows per freestall) and lying time (ratio of time relative to a 1:1 cow-tostall control) relative to values when there was a 1:1 ratio of cows to stalls. Eight studies focused on lactating dairy cows, stocking density of freestalls, and lying behavior are shown; values from the same citation represent treatments within each. 
is likely to be achieved by adding more cows to large groups, which involves changes in space availability, not only in the stalls but also in the alleyways and at the feed bunk.

Comparisons among farms in stocking density do not find the relationship with average lying time seen in the experimental studies. Deming et al. (2013) report no relationship between stocking density and lying time on 13 Canadian herds using automatic milking systems. Charlton et al. (2014) measured stocking density and lying time on 111 freestall farms in Canada. A negative correlation in the expected direction $(\mathrm{r}=-0.15)$ was found but was not statistically significant. However, no farm with a stocking density greater than 1.0 cow per stall had a lying time of $12 \mathrm{~h} / \mathrm{d}$ or more. In both studies, stocking densities were low (means 0.96 and 0.90 ), with very few farms greater than 1.1 cows per stall. In the US, more farms are overstocked (von Keyserlingk et al., 2012), but Ito et al. (2014) found no relationship between stocking density and mean lying time among 79 farms in the US, although the average values on these farms were low $(<11 \mathrm{~h} / \mathrm{d})$. It seems likely that average lying time on a farm may be more dependent on stall design and bedding type, which may mask effects of stocking density. Despite the various caveats, it is clear that higher stocking densities in freestall systems reduce opportunities to lie down, limiting the cow's ability to express her motivation to perform this behavior.

\section{Space Allowance in Non-Stall Systems}

Unfortunately, relatively little research has examined the effects of stocking density in non-stall systems on lactating cows. Lying times were higher, and aggressive behavior and disturbances to lying behavior were less common with higher space allowance $(3.0,4.5,6.0,7.5$, 9.0, and $10.5 \mathrm{~m}^{2} /$ cow; Schütz et al., 2015). Although a direct comparison was not performed, Fregonesi and Leaver (2001) reported lower mean lying times (11.8 $\mathrm{h} / \mathrm{d}$ ) of cows in straw pens with a lower space allowance $\left(9.2 \mathrm{~m}^{2} /\right.$ cow $)$ compared with that of cows with a higher space allowance $\left(13.2 \mathrm{~h} / \mathrm{d} ; 10 \mathrm{~m}^{2} / \mathrm{cow}\right)$.

The effect of stocking density on lying time of cattle in non-stall systems has been otherwise largely examined in young animals. In pens with concrete slatted floors, a reduction in space allowance from 3.0 to 1.5 $\mathrm{m}^{2}$ per animal (250-500 kg live weight) reduced lying time in heifers (Hindhede et al., 1996; Fisher et al., 1997) and steers (Hickey et al., 2003). However, a more recent study investigating the effects of reducing space allowance in pens with rubber flooring from 4.0 to $2.5 \mathrm{~m}^{2}$ /animal (350-500 kg) found no effect on lying time in bulls (Gygax et al., 2007). Among heifers (ap- proximately $300 \mathrm{~kg}$ ) in pens with slatted floor in the feeding area and deep-bedded straw in the lying area, increasing the space allowance in the lying area from $1.8 \mathrm{~m}^{2}$ per animal to 2.7 and $3.6 \mathrm{~m}^{2}$ per animal resulted in longer synchronized lying (Nielsen et al., 1997) but did not increase lying time as such (approximately 13.3 $\mathrm{h} / \mathrm{d})$.

The general picture is that a space allowance of $1.5 \mathrm{~m}^{2}$ per animal compromises lying time, but that increasing space above $3.0 \mathrm{~m}^{2}$ per animal does not increase lying time in young stock of 250 to $500 \mathrm{~kg}$. The study by Nielsen et al. (1997) suggests that heifers of approximately $300 \mathrm{~kg}$ require a minimum of $2.7 \mathrm{~m}^{2}$ per animal to lie down at the same time.

\section{Lying Surface and Stall Configuration}

An uncomfortable lying area is another obvious factor affecting the time that cows lie down. The results summarized in Table 2 show that lying times are consistently shorter on bare concrete, and adding rubber mats or geotextile mattresses to concrete floors results in higher lying times. These advantages of rubber mats or mattress are thought to be due to the greater softness or compressibility, but this assumption has rarely been tested directly. Schütz and Cox (2014) found longer lying times on 24 -mm-thick mats $(7.3 \mathrm{~h} / 18 \mathrm{~h})$ compared with 12 -mm-thick mats $(6.0 \mathrm{~h} / 18 \mathrm{~h})$. These results suggest that compressibility was an underlying factor, but we note that these treatments were not statistically different from each other.

Within the softer surfaces, no consistent differences have been found among straw, wood, rubber, and sand. One large-scale epidemiological study $(5,135$ cows on 141 farms) found that sand bedding was associated with a $1.4 \mathrm{~h} / \mathrm{d}$ greater lying time than other surfaces, but only where stall curbs were high (Solano et al., 2016). The inconsistent effects of sand bedding compared with straw or wood shavings may reflect the cows' experience with it, because lack of previous experience reduces the time spent lying down on sand (Tucker et al., 2003; Norring et al., 2008).

The relative effects of different materials may depend on their degree of heat insulation, and the temperature in the barn may be important. Bedding materials can differ greatly in the extent that they allow body heat to dissipate from the cow (Radoń et al., 2014). De Palo et al. (2006) showed that an increased temperaturehumidity index (leading to heat stress) corresponded with cows' preferences for wood shavings and dried manure compared with synthetic plastic (which had a greater degree of heat insulation). However, Manninen et al. (2002) found no differences between summer and winter in cows' preferences for straw over sand, suggest- 
ing that environmental temperature was not a factor in this experiment.

The quantity and quality of bedding provided also affect lying time. Earlier research showed that lack of bedding will generally reduce cows' lying time (reviewed in Tuyttens, 2005). More recently, Morabito et al. (2017) showed that cows on farms that provided more bedding (or used a softer lying surface) following an animal welfare assessment spent $2 \mathrm{~h} / \mathrm{d}$ longer lying than cows on farms that did not make such changes. Experimental studies have shown that providing more straw or wood shavings in stalls results in more time spent lying down in both freestalls (Tucker and Weary, 2004) and tiestalls (Tucker et al., 2009c). In tiestalls, Tucker et al. (2009c) estimated that the daily duration of lying down was increased by $3 \mathrm{~min} / \mathrm{d}$ for each additional kilogram of wood shavings added and by 12 $\mathrm{min} / \mathrm{d}$ for each additional kilogram of straw added. This effect of bedding has been confirmed in largerscale epidemiological studies of commercial herds in the US and Canada (Ito et al., 2014; Westin et al., 2016). Ito et al. (2014) found that daily lying time was on average $0.8 \mathrm{~h} / \mathrm{d}$ higher on farms that used deep bedding compared with farms that did not.

However, simply providing deep bedding is not sufficient to ensure long lying times, because the bedding tends to be unevenly distributed within the stall once the cows have occupied the stall, often resulting in a concave shape, which can also reduce lying time (Drissler et al., 2005). The dryness of the bedding also has a marked effect: wet lying areas are undesirable. When given a choice, dairy cattle clearly avoid wet sawdust in freestalls (86 vs. $27 \%$ DM; Fregonesi et al., 2007b) and in pens (Schütz et al., 2019). Indeed, they will spend less time lying down on wet surfaces compared with drier ones (Figure 4). Cows held in pens with dirt floors also spend less time lying down in muddy conditions, compared with dry soil (Chen et al., 2017), and these low lying times seem to be driven by the moisture content, rather than by contamination with manure (Schütz et al., 2019). Finally, cows spend less time lying with their head supported, a position that is likely important for sleep, in wet conditions compared with drier ones (Tucker et al., 2007b; Schütz et al., 2019).

Fewer studies have examined the effects of stall size on lying time. In experimental studies, Tucker et al. (2004) showed that stall width (but not length) influenced lying time in freestalls; it was lower in narrow stalls compared with wider ones. Epidemiological studies have found a similar result both in tiestalls (Bouffard et al., 2017) and in freestalls (Solano et al., 2016). Bouffard et al. (2017) found that stall length did not affect total lying time, but lying bout frequency was reduced when stalls were short. In conclusion, uncomfortable lying areas as a result of hard or wet surfaces, inadequate bedding, moisture, and narrow stalls clearly reduce lying time.

\section{Standing Surface}

If the surface that cows are standing on is uncomfortable, we might expect that this will increase the time that cows lie down. Conversely, more comfortable surfaces for standing may explain the lower lying time found in deep packs, in dry lots, and at pasture com-

Table 2. Mean daily duration of time $(\mathrm{h} / 24 \mathrm{~h})$ dairy cows were observed lying down on different lying surfaces in pens (PN), freestalls (FS), and tiestalls (TS); summary limited to studies with planned comparisons among lying surface types

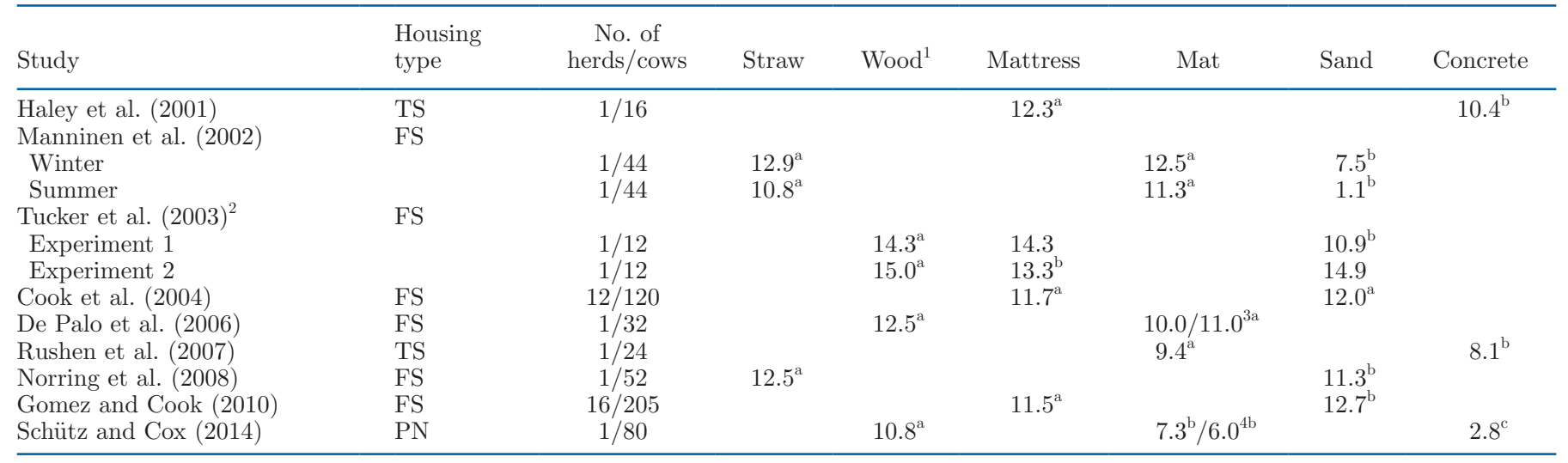

\footnotetext{
${ }^{a-c}$ Different letters indicate statistically significant treatment differences.

${ }^{1}$ Includes wood shavings, sawdust, and wood chips.

${ }^{2}$ Statistical differences reported in the paper are given; some comparisons (e.g., mattress vs. sand or wood) were not tested.

${ }^{3}$ Two types of synthetic plastic mats.

${ }^{4}$ Two thicknesses of rubber mats.
} 
pared with tiestalls and freestalls (Table 1). Research has found that the standing surface can influence lying time, but the results are not consistent. Fregonesi et al. (2004) found a longer lying time for cows housed with concrete floors in the standing areas compared with rubber, and Schütz and Cox (2014) found more time spent lying down as a result of repeated standing on concrete, but not standing on wood chips or rubber mats. However, Tucker et al. (2006) found that total lying times were longer when the cows were standing on rubber compared with concrete, but this may be because the animals began to lie in the feed alley when this softer surface was provided. In an epidemiological study, Solano et al. (2016) found longer lying times for cows standing on rubber floors compared with slatted concrete floors, but not compared with solid concrete floors. Taken together, the literature gives no consistent evidence that the surface provided for standing influences lying time, but the research to date has examined a narrow range of surfaces and has not studied pasture or the type of standing surfaces found in deep bedding or dry lots.

What the cow does on the standing surface (stand still, walk, graze, run, or other activity) and how much control she has while standing (e.g., restrained head lock, tiestall, or stanchion vs. being unrestrained) also likely affects the way she distributes her time between lying down and standing, and how she structures standing and lying bouts. However, these dimensions have not been examined in any systematic way. Untangling the effects of surface quality, behavior while upright, and how much control the cow has are important priorities for future research.

\section{Weather and Climate}

Numerous studies consistently report that, as ambient temperatures increase in summer, dairy cows spend less time lying down (Shultz, 1984; Wagner-Storch et al., 2003; Cook et al., 2004, 2007; Zähner et al., 2004; Tapkı and Şahin, 2006; Tucker et al., 2008; Schütz et al., 2010b, 2020; Legrand et al., 2011; Chen et al., 2013, 2016a; Mattachini et al., 2017; Tresoldi et al., 2019), regardless of provision of heat abatement (Overton et al., 2002; Legrand et al., 2011; Chen et al., 2013, 2016a). Both Chen et al. (2016a) and Tresoldi et al. (2019) found that daily lying time is reduced by 21 to 22 min for every $1^{\circ} \mathrm{C}$ increase in ambient temperature, within the range tested, whereas King et al. (2016) report a more modest 15-min reduction for every additional $10^{\circ} \mathrm{C}$. Fewer studies have examined the effects of winter weather. One study found that beef cows spent more time lying down in cool weather than in warmer weather (Malechek and Smith, 1976), and cows reduce lying time in response to rain in winter conditions (Schütz et al., 2010a; O'Connor et al., 2019; Thompson et al., 2019). Indeed, if they have the option of being indoors, cows avoid going outside during rainy periods (Legrand et al., 2009; Charlton et al., 2011; Falk et al., 2012; Smid et al., 2019).

The reasons for the effects of weather are speculative. Lying down may reduce the surface area exposed

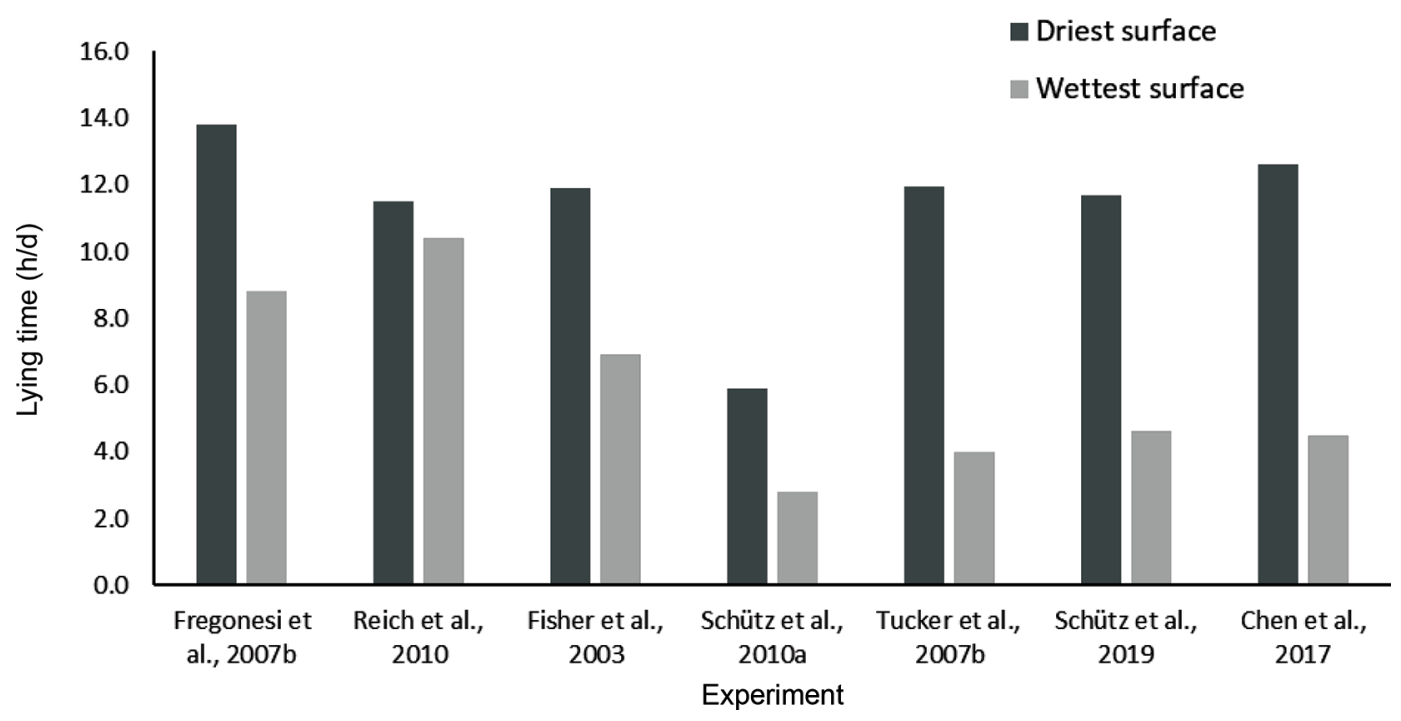

Figure 4. Mean lying times (hours per time on a given surface in a day) for 7 experiments (Fisher et al., 2003; Fregonesi et al., 2007b; Tucker et al., 2007b; Reich et al., 2010; Schütz et al., 2010a; Chen et al., 2017; Schütz et al., 2019) that compared lying surfaces that differed in moisture content. If several treatments were included in a study, comparable wettest and driest lying surfaces are shown. 
to wind and solar radiation and, thus, affect heat loss or gain (e.g., Gonyou et al., 1979; Redbo et al., 1996; Olson and Wallander, 2002) or may make respiration, a key mechanism for cooling in cattle, less effective. In addition, the effectiveness of heat loss while lying may also be dependent on the conductivity of the surface provided. Although the mechanism underlying why cows stand more in hot weather is not understood, some evidence indicates that thermodynamics play a role (Nordlund et al., 2019).

\section{Environmental Factors Affecting Lying Time- Summary and Conclusions}

A large body of research shows that the lying time of cows can be affected by many housing and farm management factors. Cows in tiestall and freestall systems lie down, on average, between 10 and $12 \mathrm{~h} / \mathrm{d}$, whereas cows in bedded packs, dry lots, and pasture lie for about $9 \mathrm{~h} / \mathrm{d}$. Management decisions, such as long milking times, force cows to stand and limit their ability to express their motivation to lie down. Lower lying times also result from unfavorable housing conditions, including too few lying stalls for the number of cows, a lack of cow comfort resulting from hard or wet lying surfaces, inadequate bedding, or stalls that are too small. We also do not fully understand whether or when environmental factors compromise welfare. The implications of long grazing times and relatively low lying times on pasture are unclear, especially if the adequacy of the feed level is unknown. Similarly, if adequate heat abatement is provided and a cow still choses to spend less time lying, we would need more information, especially in terms of the biological consequences, to know whether this is a problem or not. Finally, an interaction among the different factors is likely: for example, the effects of prolonged milking times are likely to be exacerbated if feeding routines take a long time and if stocking density is high. The nature and effect of these interactions on lying time have not been adequately explored.

\section{ANIMAL-BASED SOURCES OF VARIATION IN LYING TIME}

On any farm, large differences in lying time may occur among individual cows. An important question is whether differences among individual cows reflect differences in welfare status or whether they are neutral.

\section{IIIness and Injury}

A clear link between lying time and animal welfare is shown when changes result from illness or injury. Our review focuses on lameness and mastitis as examples to highlight the challenges of interpreting changes in lying time associated with health concerns. Across the literature, studies have found that lame cows spend more time lying down than nonlame ones (23 out of 27 comparisons; Figure 5) in freestalls and at pasture. These patterns are not always statistically significant within a given study, but the pattern across this literature is clear. Large-scale epidemiological studies find that lame cows in freestalls lie down for longer in fewer, longer bouts (Solano et al., 2016; Westin et al., 2016), with no difference in tiestalls (Charlton et al., 2016).

In contrast with lame cows, cows with mastitis spend less time lying down than controls (Figure 5). Both lameness and mastitis are known to be painful (e.g., Flower et al., 2008; Fitzpatrick et al., 2013), but an affected hoof or leg changes lying behavior in a different manner than an affected udder. Thus far, little work has examined the relationship between lying time and other types of infection or injury in dairy cattle. For example, Itle et al. (2015) found that cows suffering from ketosis spent less time lying soon after parturition, compared with healthy cows, and Villettaz Robichaud et al. (2019) reported that freestall herds with longer lying times also have fewer hock injuries. However, others have reported that cows with higher lying times are also at greater risk for culling in the first 60 DIM (Piñeiro et al., 2019).

These types of results lead to the obvious question: do measures of lying time help detect sick animals or farms with problems? This has been examined most with lameness. Average lying times on a farm did not appear to be associated with the farm prevalence of lameness (Solano et al., 2016), suggesting that measures of herd lying times may not be helpful in identifying farms with this problem. However, although lame cows clearly spend more time lying down than sound cows do, using measures of lying behavior to identify this problem has had mixed success. This research has been reviewed by Van Nuffel et al. (2015), who found that a lying time greater than $14 \mathrm{~h} / \mathrm{d}$ increased the odds that the cow was lame by 3.7 , but the threshold had unacceptably low sensitivity and specificity.

\section{Age and Parity}

Age and parity do not appear to influence lying time in a consistent way, and a direct comparison among studies is difficult, as some are experimental and others epidemiological in nature. However, some experiments (Sepúlveda-Varas et al., 2014; Westin et al., 2016; Stone et al., 2017; Henriksen et al., 2019) report more lying time with higher parity, varying between 0.5 and $1 \mathrm{~h}$, whereas others report no difference (Chaplin and Munksgaard, 2001; Bewley et al., 2010) or slightly re- 


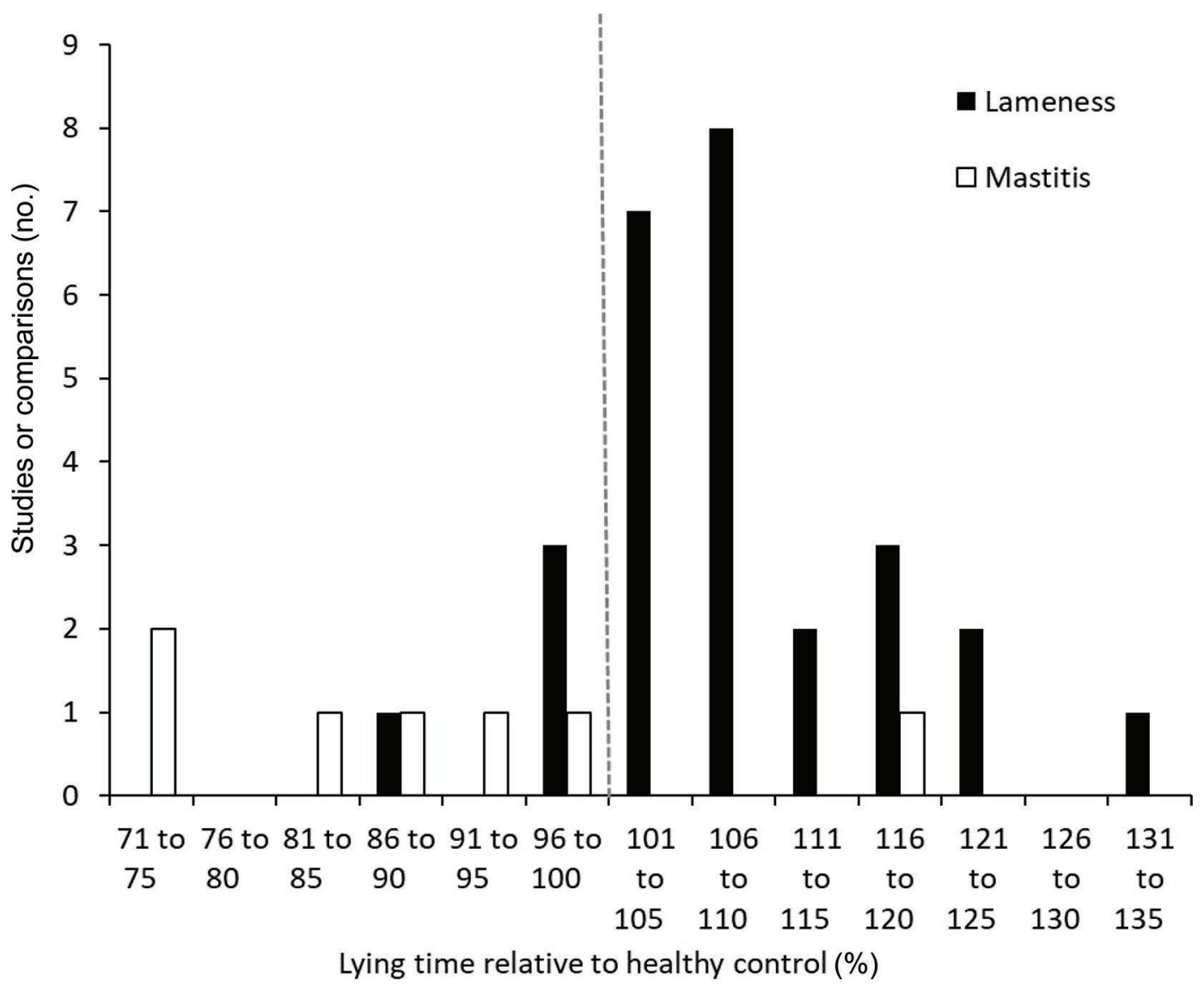

Figure 5. Number of experiments (or comparisons within experiments) examining the effects of lying time in lame ( $\mathrm{n}=19$ papers, 27 comparisons; Hassall et al., 1993; Singh et al., 1993; Cook et al., 2004; Walker et al., 2008; Chapinal et al., 2010a,b; Ito et al., 2010; Blackie et al., 2011; Calderon and Cook, 2011; Thomsen et al., 2012; Yunta et al., 2012; Navarro et al., 2013; Sepúlveda-Varas et al., 2014; Charlton et al., 2016; Solano et al., 2016; Westin et al., 2016; Weigele et al., 2018; Blackie and Maclaurin, 2019; Thompson et al., 2019) or mastitic cows relative to controls ( $\mathrm{n}=7$ papers; Siivonen et al., 2011b; Zimov et al., 2011; Cyples et al., 2012; Fogsgaard et al., 2012; Medrano-Galarza et al., 2012; Yeiser et al., 2012; Fogsgaard et al., 2015). The dashed vertical line indicates 100\%, or that the control and affected animals had the same values.

duced lying times for cows in third or higher parities (-12 $\mathrm{min} / \mathrm{d}$; Brzozowska et al., 2014). Solano et al. (2016) found that among cows in freestalls, multiparous cows had longer lying times only early in lactation. Similarly, Vasseur et al. (2012) report a complex interaction between parity, stage of lactation, and type of housing. The only longitudinal study reported to date found that lying times in both Holstein and Jersey cows were lower in first-parity cows during the first months of lactation, and then this difference between parities disappeared (Henriksen et al., 2019; Munksgaard et al., 2020). We found no evidence to help us decide whether these age-related changes reflect changes in the animal's welfare.

\section{Reproductive State and Stage of Lactation}

The time spent lying down is affected by animals' reproductive state (Silper et al., 2017). On the day of estrus, cows show a marked increase in activity, mainly involving more time spent walking, which is associated with a reduction in the duration of lying down (e.g., Jónsson et al., 2011; Dolecheck et al., 2015; Silper et al., 2015). The reduction in time spent lying down can be substantial: Silper et al. (2015) reported that nulliparous cows spent 37\% less time lying on the day of estrus. Similarly, Dolecheck et al. (2015) found that during the $6 \mathrm{~h}$ on either side of the beginning of an estrus episode, multiparous cows lie down for only $40 \%$ of the time that they normally do on non-estrus days.

Parturition is associated with a reduction in lying time (Jensen, 2011; Miedema et al., 2011). Among cows with easy and unassisted calving, a marked increase in lying bouts is seen starting $6 \mathrm{~h}$ before calving, and during the final $24 \mathrm{~h}$ before calving, the time spent lying down is reduced by approximately $1 \mathrm{~h}$ (Jensen, 2011; Miedema et al., 2011). This may be due to discomfort during contractions, which also increases markedly dur- 
ing this period (Jensen, 2011). During the first hours after parturition, licking and nursing are priorities, at the expense of lying down (Jensen, 2011; Campler et al., 2015). Once parturition is finished, earlier studies suggested that lying time increases as DIM increase for cows both in tiestalls (Chaplin and Munksgaard, 2001; Vasseur et al., 2012) and in freestalls (Nielsen et al., 2000; Munksgaard et al., 2005; Bewley et al., 2010; Vasseur et al., 2012; Deming et al., 2013; Solano et al., 2016; Westin et al., 2016). Among cows on pasture, after an initial increase during the first $3 \mathrm{~d}$, lying time also declined during the first month after calving (Hendriks et al., 2019). However, more recent studies using longitudinal measures suggest that lying time among cows in freestalls decreases to a nadir around 1 mo after calving, after which it increases in cows in second or later lactation (Maselyne et al., 2017; Munksgaard et al., 2020). Whether these changes in lying time are due to recovery from calving, physiological changes in the transition period, changes in milk production, or stage of pregnancy has not been examined, nor did we find any evidence that the short-term changes at the time of parturition affect the welfare of the animals.

\section{Milk Production}

Many studies have reported a negative relationship between milk yield and daily lying duration in different housing systems (Fregonesi and Leaver, 2002; Bewley et al., 2010; Norring et al., 2012; Vasseur et al., 2012; Deming et al., 2013; Watters et al., 2013; Løvendahl and Munksgaard, 2016; Stone et al., 2017). Several lines of evidence suggest that cows with higher yield have more milk in the udder closer to milking, which may make lying down painful. The proportion of time spent lying decreases with time since milking (Overton et al., 2002), and cows with higher score for udder pressure, due to omitting a milking, tend to have shorter lying bouts (Stefanowska et al., 2000; O'Driscoll et al., 2011). Lying time during the last $4 \mathrm{~h}$ before morning milking is reduced in cows milked $2 \times$ compared with $3 \times$ per day (Österman and Redbo, 2001). However, at dry-off the results are not all supportive of the idea that lying with a full udder affects lying behavior (reviewed by Zobel et al., 2015, and more recently studied by RajalaSchultz et al., 2018; Dancy et al., 2019).

Alternatively, or additionally, the relationship between milk yield and lying time may reflect the fact that cows with higher yield have a higher energy demand and spend more time feeding, leaving less time available for lying down (Cook, 2020). In support of this, Løvendahl and Munksgaard (2016) observed that first-lactation cows with higher yield fed longer and spent less time lying down, compared with those with lower yield. This may reflect a simple adaptation to the higher energy demand due to increased production. However, for some high-producing cows, time constraints may result in reduced feed intake and lying time (Munksgaard et al., 2005), especially if other factors, such as stocking density, time away for milking, and more, leave limited time available for lying and eating. As yet we do not know the full welfare consequences of this tradeoff, but continued selection for higher milk yield will require that the environment or management give the cows enough time for both lying down and feeding.

\section{Animal-Based Factors-Summary and Conclusions}

The lying time of individual cows within a herd will be affected by their parity, reproductive state, and level of milk production. Some of the variation in lying time is clearly related to animal welfare: lying time is higher in lame cows and lower in those with mastitis. However, we lack sufficient evidence of the extent to which measures of lying time could identify lame or mastitic cows. We found no evidence to determine whether the effects on lying time of parity, reproductive state, or milk yield are related to the welfare of the animals. Therefore, studies on the motivation of cows to lie down need to include these different states. These animal-based factors may interact to exacerbate the effects of farm housing and management on lying time.

\section{IMPLICATIONS FOR ANIMAL WELFARE AND FUTURE DIRECTIONS}

Being healthy and being able to perform highly motivated behaviors are key requirements for good welfare (Dawkins, 2004). In this review, we clearly demonstrate that forcing cows to stand for $3+\mathrm{h}$ at a time or providing them with unfavorable lying conditions risks compromising their welfare. We see this in several ways. In terms of motivation, there are lines of convincing evidence that lying behavior is a high-priority behavior for cattle (behavioral tradeoffs, measures of demand), that the motivation to lie down increases when cows are unable to do so (rebound after standing, indicators of possible frustration), and that behavioral and physiological consequences occur when this motivation is thwarted. In terms of how health is affected, we have limited but biologically reasonable evidence that the risk of lameness is higher when cows are in environments that provide unfavorable conditions for cows to lie down and when cows are forced to stand, at least during the transition period.

A key question about lying time and animal welfare is whether a threshold exists in terms of number of 
hours per day that cows must lie down to avoid negative effects. Several types of evidence must be considered in this question. The first is to look at patterns across farms and experiments (Table 1; Figure 2). Cows in tiestall and freestall systems lie down, on average, between 10 and $12 \mathrm{~h} / \mathrm{d}$, whereas cows in bedded packs, dry lots, and pasture lie for about $9 \mathrm{~h} / \mathrm{d}$. We do not yet understand the reasons for these differences due to housing type. For cows at pasture, a longer time required for grazing may result in the low lying times (Figure 2). It is also possible that the comfort of the standing surface plays a role. Across systems, it seems that a reasonable starting place for a threshold for lying time is between 9 and $12 \mathrm{~h} / \mathrm{d}$, and that this could be used as "reference range," similar to how health indicators are presented in the field of human medicine. The amount of data available to include in these estimates is considerable, especially for Holstein cows in tiestalls and freestalls. However, these values come from farms where common animal welfare concerns occur, such as lameness and leg injuries (Cook, 2018), raising some doubt as to the extent that we can use data from commercial farms to estimate or understand optimal lying times.

The second set of evidence about the number of hours of lying down per day comes from experiments examining motivation and changes in biological function. These studies clearly show that lying is a highpriority behavior for cattle. However, extrapolating a daily threshold from them presents challenges. Most studies reduced lying time by forcing cows to stand or by keeping them in unfavorable conditions, relative to a control, and in some cases, the treatments imposed are extreme, such as $6+$ consecutive hours of standing. It is also unclear how well these studies represent on-farm situations. For example, we do not know whether $6 \mathrm{~h}$ of consecutive standing is equivalent to three 2 -h milking events for cows. Many of these studies use heifers or dry cows, making it difficult know how the number of hours per day translate into values for lactating cows and their higher metabolic demands. To further complicate the matter, high lying times are associated with some painful conditions (lameness; Figure 5). In addition, low lying times occur in situations where the link to animal welfare is not clear (e.g., estrus, grazing at pasture). Although we agree that animal welfare concerns arise if animals are ill or their motivation to lie down is thwarted by how they are housed or managed, these exceptions complicate a straightforward interpretation of daily lying time as a measure of animal welfare. Low lying times do not inevitably mean that animal welfare is at risk, nor do long lying times inevitably guarantee good animal welfare. Recommended thresholds, such as 10 to 12 h/d (Recommended Best Practice, Ministry for Primary Industries, 2019, New Zealand) or $12 \mathrm{~h} / \mathrm{d}$ (National Farm Animal Care Council, 2009, Canada), are helpful guidelines as to the importance of lying time for cattle and provide context about what is common. However, as with any measure of animal welfare, they should not be used in isolation. We recommend that such thresholds be used in combination with other animal- and input- or facility-based measures to gauge risk to dairy cattle welfare (Figure 6).

In terms of future research, we find several key priorities. The first research priority is to better understand the quality of lying time for cattle and the effects of the environment - both in terms of the physical surroundings as well as the social conditions - on these outcomes. To date, we largely treat all time cattle spend lying down as the same, but this is an assumption that has not been challenged or explored. Most importantly, we do not know how changes in lying time are related to sleep duration and quality. Second, how lying behavior changes in more complex environments, and to what extent inactivity and lying down is related to limited stimulation of exploratory behavior in unvarying or unstimulating ones, has not been explored in cattle. This topic has garnered attention in other species (Fureix and Meagher, 2015; Burn, 2017; Meagher, 2019) and warrants consideration, to aid our interpretation of what lying time means to dairy cattle. Finally, we need to better understand the motivation underlying why cows stand. Many of the studies summarized in this review experimentally forced cows to stand, and, on farm, cows are forced to stand during milking times and while being restrained for herd health checks and breeding protocols. However, little is known about the patterns of standing bouts in cattle; for example, how long will they voluntarily stand, and how does that vary across farms? The welfare implications of standing are also likely affected by what the cows do while upright. Standing and walking on concrete or standing on concrete while restrained may have different implications compared with walking while grazing, for example. Little is known about any of this, yet it has important implications for cattle welfare, and sensors to detect lying and standing, as well as technology to determine whether cows are at milking (Thompson et al., 2017), will allow us to rapidly gain this knowledge. Indeed, standing time requires the same in-depth study that lying time and bout structure have received.

\section{CONCLUSIONS}

Being able to lie down is a high priority for dairy cows, and animal welfare can be at risk when this behavior is thwarted. Lying behavior should be facilitated on farms through the provision of soft, dry, 


\begin{tabular}{|c|c|c|}
\hline $\begin{array}{l}\text { Potential risk to } \\
\text { welfare }\end{array}$ & Lying time below 10-12 h/d threshold & Lying time at or above $10-12 \mathrm{~h} / \mathrm{d}$ threshold \\
\hline High & $\begin{array}{l}\text { - Unfavorable lying conditions }{ }^{1} \\
\text { - Unfavorable standing conditions }{ }^{2} \\
\text { - Lying time is reduced by time constraints (e.g. long milking times, } \\
\text { restraint, time required for feeding) } \\
\text { - Lying time reduced by disease (e.g. mastitis) or injury } \\
\text { - Rain or unmitigated heat load }\end{array}$ & $\begin{array}{l}\text { - Longer lying times associated disease (e.g. lameness) or } \\
\text { injury }\end{array}$ \\
\hline $\begin{array}{l}\text { Unknown, either } \\
\text { not yet studied or } \\
\text { no evidence of } \\
\text { risk, to date }\end{array}$ & $\begin{array}{l}\text { - Estrus } \\
\text { - Hours around parturition } \\
\text { - Lying time is reduced because cows are motivated to graze, engage } \\
\text { in other behaviors (e.g. social interactions) or remain upright in } \\
\text { response to mitigated heat load }\end{array}$ & $\begin{array}{l}\text { - Unstimulating environments and lack of alternative } \\
\text { activities }\end{array}$ \\
\hline
\end{tabular}

${ }^{1}$ wet, poorly bedded mats/mattresses/concrete, poorly designed lying areas, or limited availability of lying spaces

${ }^{2}$ wet, manure-covered, slippery, rocky, or hard (concrete) surfaces

Figure 6. A summary of situations in which deviations from a daily lying time threshold of 10 to 12 h/d (e.g., National Farm Animal Care Council, 2009, Canada; Ministry for Primary Industries, 2019, New Zealand) may indicate low or high risks to animal welfare, or where the likelihood of welfare risks is unknown. The boxes outlined in green indicate the situations when deviations from a threshold of 10 to $12 \mathrm{~h} / \mathrm{d}$ could likely accurately detect a threat to welfare and also identify comfortable cows. However, other situations also exist in which less is known; thus, measures of daily lying time should be used in combination with other animal- and input- or facility-based measures when assessing animal welfare.

clean, accessible, well-designed, and appropriately sized lying areas and limited exposure to constraints such as long milking, restraint, or feeding times, or hot or rainy weather. The status of the cow, including her reproductive status, days since calving, age, and disease burden also influence how much time she spends lying and should be considered, along with details about the suitability of the housing and management, when interpreting measures of daily lying time in the assessment of animal welfare.

\section{ACKNOWLEDGMENTS}

We profoundly thank Lene Munksgaard (Aarhus University, Foulum, Denmark) for bringing us together as a writing and thinking team and for all of her many contributions to our discussions and to this manuscript. It would not have been possible without her. We also thank Rachael Coon (University of California, Davis) for her help organizing and searching for references for Figure 2. Karin Schütz (AgResearch Ltd., Hamilton, New Zealand) and two anonymous reviewers provided valuable feedback on earlier drafts. The authors have not stated any conflicts of interest.

\section{REFERENCES}

Bak, A. S., M. S. Herskin, and M. B. Jensen. 2016. Effect of sand and rubber surface on the lying behavior of lame dairy cows in hospital pens. J. Dairy Sci. 99:2875-2883. https://doi.org/10.3168/jds.2015 $-9937$.

Beauchemin, K. A. 2018. Invited review: Current perspectives on eating and rumination activity in dairy cows. J. Dairy Sci. 101:47624784. https://doi.org/10.3168/jds.2017-13706.

Beggs, D. S., E. C. Jongman, P. E. Hemsworth, and A. D. Fisher. 2018. Implications of prolonged milking time on time budgets and lying behavior of cows in large pasture-based dairy herds. J. Dairy Sci. 101:10391-10397. https://doi.org/10.3168/jds.2018-15049.

Bell, N. J., M. J. Bell, T. G. Knowles, H. R. Whay, D. J. Main, and A. J. F. Webster. 2009. The development, implementation and testing of a lameness control programme based on HACCP principles and designed for heifers on dairy farms. Vet. J. 180:178-188. https:// doi.org/10.1016/j.tvjl.2008.05.020.

Bewley, J. M., R. E. Boyce, J. Hockin, L. Munksgaard, S. D. Eicher, M. E. Einstein, and M. M. Schutz. 2010. Influence of milk yield, stage of lactation, and body condition on dairy cattle lying behaviour measured using an automated activity monitoring sensor. J. Dairy Res. 77:1-6. https://doi.org/10.1017/S0022029909990227.

Blackie, N., J. Amory, E. Bleach, and J. Scaife. 2011. The effect of lameness on lying behaviour of zero grazed Holstein dairy cattle. Appl. Anim. Behav. Sci. 134:85-91. https://doi.org/10.1016/j .applanim.2011.08.004

Blackie, N., and L. Maclaurin. 2019. Influence of lameness on the lying behaviour of zero-grazed lactating Jersey dairy cattle housed in straw yards. Animals (Basel) 9:829. https://doi.org/10.3390/ ani9100829.

Blokhuis, H. J., I. Veissier, M. Miele, and B. Jones. 2010. The Welfare Quality project and beyond: Safeguarding farm animal well-being. Acta Agric. Scand. A Anim. Sci. 60:129-140. https://doi.org/10 $.1080 / 09064702.2010 .523480$.

Bolinger, D. J., J. L. Albright, J. Morrow-Tesch, S. J. Kenyon, and M. D. Cunningham. 1997. The effects of restraint using self-locking stanchions on dairy cows in relation to behavior, feed intake, physiological parameters, health, and milk yield. J. Dairy Sci. 80:24112417. https://doi.org/10.3168/jds.S0022-0302(97)76193-9.

Borchers, M. R., Y. M. Chang, I. C. Tsai, B. A. Wadsworth, and J. M. Bewley. 2016. A validation of technologies monitoring dairy cow 
feeding, ruminating, and lying behaviors. J. Dairy Sci. 99:74587466. https://doi.org/10.3168/jds.2015-10843.

Bouffard, V., A. M. de Passillé, J. Rushen, E. Vasseur, C. G. R. Nash, D. B. Haley, and D. Pellerin. 2017. Effect of following recommendations for tiestall configuration on neck and leg lesions, lameness, cleanliness, and lying time in dairy cows. J. Dairy Sci. 100:29352943. https://doi.org/10.3168/jds.2016-11842.

Brzozowska, A., M. Łukaszewicz, G. Sender, D. Kolasińska, and J. Oprządek. 2014. Locomotor activity of dairy cows in relation to season and lactation. Appl. Anim. Behav. Sci. 156:6-11. https:// doi.org/10.1016/j.applanim.2014.04.009.

Burn, C. C. 2017. Bestial boredom: A biological perspective on animal boredom and suggestions for its scientific investigation. Anim. Behav. 130:141-151. https://doi.org/10.1016/j.anbehav.2017.06.006.

Calderon, D. F., and N. B. Cook. 2011. The effect of lameness on the resting behavior and metabolic status of dairy cattle during the transition period in a freestall-housed dairy herd. J. Dairy Sci. 94:2883-2894. https://doi.org/10.3168/jds.2010-3855.

Campler, M., L. Munksgaard, and M. B. Jensen. 2015. The effect of housing on calving behavior and calf vitality in Holstein and Jersey dairy cows. J. Dairy Sci. 98:1797-1804. https://doi.org/10 $.3168 /$ jds.2014-8726.

Ceballos, A., D. Sanderson, J. Rushen, and D. M. Weary. 2004. Improving stall design: Use of 3-D kinematics to measure space use by dairy cows when lying down. J. Dairy Sci. 87:2042-2050. https: //doi.org/10.3168/jds.S0022-0302(04)70022-3.

Chapinal, N., A. M. de Passillé, J. Rushen, and C. B. Tucker. 2011. Short communication: Measures of weight distribution and frequency of steps as indicators of restless behavior. J. Dairy Sci. 94:800-803. https://doi.org/10.3168/jds.2010-3531.

Chapinal, N., A. M. de Passillé, J. Rushen, and S. Wagner. 2010a. Automated methods for detecting lameness and measuring analgesia in dairy cattle. J. Dairy Sci. 93:2007-2013. https://doi.org/10 $.3168 /$ jds.2009-2803.

Chapinal, N., A. M. de Passillé, J. Rushen, and S. A. Wagner. 2010b. Effect of analgesia during hoof trimming on gait, weight distribution, and activity of dairy cattle. J. Dairy Sci. 93:3039-3046. https: //doi.org/10.3168/jds.2009-2987.

Chapinal, N., A. M. de Passillé, D. M. Weary, M. A. G. von Keyserlingk, and J. Rushen. 2009. Using gait score, walking speed, and lying behavior to detect hoof lesions in dairy cows. J. Dairy Sci. 92:4365-4374. https://doi.org/10.3168/jds.2009-2115.

Chapinal, N., and C. B. Tucker. 2012. Validation of an automated method to count steps while cows stand on a weighing platform and its application as a measure to detect lameness. J. Dairy Sci. 95:6523-6528. https://doi.org/10.3168/jds.2012-5742.

Chaplin, S., and L. Munksgaard. 2001. Evaluation of a simple method for assessment of rising behaviour in tethered dairy cows. Anim. Sci. 72:191-197. https://doi.org/10.1017/S1357729800055685.

Charlton, G. L., V. Bouffard, J. Gibbons, E. Vasseur, D. B. Haley, D. Pellerin, J. Rushen, and A. M. de Passillé. 2016. Can automated measures of lying time help assess lameness and leg lesions on tiestall dairy farms? Appl. Anim. Behav. Sci. 175:14-22. https://doi .org/10.1016/j.applanim.2015.02.011.

Charlton, G. L., D. B. Haley, J. Rushen, and A. M. de Passillé. 2014. Stocking density, milking duration, and lying times of lactating cows on Canadian freestall dairy farms. J. Dairy Sci. 97:26942700. https://doi.org/10.3168/jds.2013-6923.

Charlton, G. L., S. M. Rutter, M. East, and L. A. Sinclair. 2011. Preference of dairy cows: Indoor cubicle housing with access to a total mixed ration vs. access to pasture. Appl. Anim. Behav. Sci. 130:1-9. https://doi.org/10.1016/j.applanim.2010.11.018.

Chen, J. M., K. E. Schütz, and C. B. Tucker. 2013. Dairy cows use and prefer feed bunks fitted with sprinklers. J. Dairy Sci. 96:50355045. https://doi.org/10.3168/jds.2012-6282.

Chen, J. M., K. E. Schütz, and C. B. Tucker. 2016a. Cooling cows efficiently with water spray: Behavioral, physiological, and production responses to sprinklers at the feed bunk. J. Dairy Sci. 99:4607-4618. https://doi.org/10.3168/jds.2015-10714.

Chen, J. M., K. E. Schütz, and C. B. Tucker. 2016b. Technical note: Comparison of instantaneous sampling and continuous observa- tion of dairy cattle behavior in freestall housing. J. Dairy Sci. 99:8341-8346. https://doi.org/10.3168/jds.2016-11351.

Chen, J. M., C. L. Stull, D. N. Ledgerwood, and C. B. Tucker. 2017. Muddy conditions reduce hygiene and lying time in dairy cattle and increase time spent on concrete. J. Dairy Sci. 100:2090-2103. https://doi.org/10.3168/jds.2016-11972.

Collings, L. K. M., D. M. Weary, N. Chapinal, and M. A. G. von Keyserlingk. 2011. Temporal feed restriction and overstocking increase competition for feed by dairy cattle. J. Dairy Sci. 94:5480-5486. https://doi.org/10.3168/jds.2011-4370.

Cook, N. B. 2018. Assessment of cattle welfare: Common animal-based measures. In Advances in Cattle Welfare. C. B. Tucker, ed. Elsevier, Duxford, UK.

Cook, N. B. 2020. The impact of management and facilities on cow culling rates. J. Dairy Sci. 103:3846-3855. https://doi.org/10 .3168/jds.2019-17140.

Cook, N. B., T. B. Bennett, and K. V. Nordlund. 2004. Effect of free stall surface on daily activity patterns in dairy cows with relevance to lameness prevalence. J. Dairy Sci. 87:2912-2922. https://doi .org/10.3168/jds.S0022-0302(04)73422-0.

Cook, N. B., R. L. Mentink, T. B. Bennett, and K. Burgi. 2007. The effect of heat stress and lameness on time budgets of lactating dairy cows. J. Dairy Sci. 90:1674-1682. https://doi.org/10.3168/ jds.2006-634.

Cooper, M. D., D. R. Arney, and C. J. C. Phillips. 2007. Two- or fourhour lying deprivation on the behavior of lactating dairy cows. J. Dairy Sci. 90:1149-1158. https://doi.org/10.3168/jds.S0022 $-0302(07) 71601-6$

Cortés Fernández de Arcipreste, N., K. F. Mancera, G. G. MiguelPacheco, and F. Galindo. 2018. Plasticity and consistency of lying and ruminating behaviours of heifers exposed to different cubicle availability: A glance at individuality. Appl. Anim. Behav. Sci. 205:1-7. https://doi.org/10.1016/j.applanim.2018.05.020.

Crossley, R. E., A. Harlander-Matauschek, and T. J. DeVries. 2017. Variability in behavior and production among dairy cows fed under differing levels of competition. J. Dairy Sci. 100:3825-3838. https://doi.org/10.3168/jds.2016-12108.

Cyples, J. A., C. E. Fitzpatrick, K. E. Leslie, T. J. DeVries, D. B. Haley, and N. Chapinal. 2012. Short communication: The effects of experimentally induced Escherichia coli clinical mastitis on lying behavior of dairy cows. J. Dairy Sci. 95:2571-2575. https://doi .org/10.3168/jds.2011-5135.

Dado, R. G., and M. S. Allen. 1994. Variation in and relationships among feeding, chewing and drinking variables for lactating dairy cows. J. Dairy Sci. 77:132-144. https://doi.org/10.3168/jds.S0022 -0302(94)76936-8.

Dancy, K. M., E. S. Ribeiro, and T. J. DeVries. 2019. Effect of dietary transition at dry off on the behavior and physiology of dairy cows. J. Dairy Sci. 102:4387-4402. https://doi.org/10.3168/jds.2018 $-15718$.

Dawkins, M. S. 2004. Using behaviour to assess animal welfare. Anim. Welf. 13:S3-S7.

De Palo, P., A. Tateo, F. Zezza, M. Corrente, and P. Centoducati. 2006. Influence of free-stall flooring on comfort and hygiene of dairy cows during warm climatic conditions. J. Dairy Sci. 89:45834595. https://doi.org/10.3168/jds.S0022-0302(06)72508-5.

Deming, J. A., R. Bergeron, K. E. Leslie, and T. J. DeVries. 2013. Associations of housing, management, milking activity, and standing and lying behavior of dairy cows milked in automatic systems. J. Dairy Sci. 96:344-351. https://doi.org/10.3168/jds.2012-5985.

DeVries, T. J., M. G. Aarnoudse, H. W. Barkema, K. E. Leslie, and M. A. G. von Keyserlingk. 2012. Associations of dairy cow behavior, barn hygiene, cow hygiene, and risk of elevated somatic cell count. J. Dairy Sci. 95:5730-5739. https://doi.org/10.3168/ jds.2012-5375.

DeVries, T. J., S. Dufour, and D. T. Scholl. 2010. Relationship between feeding strategy, lying behavior patterns, and incidence of intramammary infection in dairy cows. J. Dairy Sci. 93:1987-1997. https://doi.org/10.3168/jds.2009-2692.

DeVries, T. J., M. Vankova, D. M. Veira, and M. A. G. von Keyserlingk. 2007. Short communication: Usage of mechanical brushes by 
lactating dairy cows. J. Dairy Sci. 90:2241-2245. https://doi.org/ 10.3168/jds.2006-648.

DeVries, T. J., and M. A. G. von Keyserlingk. 2005. Time of feed delivery affects the feeding and lying patterns of dairy cows. J. Dairy Sci. 88:625-631. https://doi.org/10.3168/jds.S0022-0302(05)72726 -0 .

Dippel, S., M. Dolezal, C. Brenninkmeyer, J. Brinkmann, S. March, U. Knierim, and C. Winckler. 2009. Risk factors for lameness in freestall-housed dairy cows across two breeds, farming systems, and countries. J. Dairy Sci. 92:5476-5486. https://doi.org/10 $.3168 /$ jds.2009-2288.

Dippel, S., C. B. Tucker, C. Winckler, and D. M. Weary. 2011. Effects of behaviour on the development of claw lesions in early lactation dairy cows. Appl. Anim. Behav. Sci. 134:16-22. https://doi.org/10 .1016/j.applanim.2011.06.006.

Dohme-Meier, F., L. D. Kaufmann, S. Görs, P. Junghans, C. C. Metges, H. A. van Dorland, R. M. Bruckmaier, and A. Münger. 2014. Comparison of energy expenditure, eating pattern and physical activity of grazing and zero-grazing dairy cows at different time points during lactation. Livest. Sci. 162:86-96. https://doi.org/10 .1016/j.livsci.2014.01.006.

Dolecheck, K. A., W. J. Silvia, G. Heersche Jr., Y. M. Chang, D. L. Ray, A. E. Stone, B. A. Wadsworth, and J. M. Bewley. 2015. Behavioral and physiological changes around estrus events identified using multiple automated monitoring technologies. J. Dairy Sci. 98:8723-8731. https://doi.org/10.3168/jds.2015-9645.

Drissler, M., M. Gaworski, C. B. Tucker, and D. M. Weary. 2005. Freestall maintenance: Effects on lying behavior of dairy cattle. J. Dairy Sci. 88:2381-2387. https://doi.org/10.3168/jds.S0022 -0302(05) 72916-7.

Endres, M. I., and A. E. Barberg. 2007. Behavior of dairy cows in an alternative bedded-pack housing system. J. Dairy Sci. 90:41924200. https://doi.org/10.3168/jds.2006-751.

European Food Safety Authority Panel on Animal Health and Welfare. 2009. Scientific report on the effects of farming systems on dairy cow welfare and disease. EFSA-Q-2006-113. Parma, Italy. https:// doi.org/10.2903/j.efsa.2009.1143r.

European Food Safety Authority Panel on Animal Health and Welfare. 2012. Scientific opinion on the use of animal-based measures to assess welfare of dairy cow. EFSA J. 10:1-81. https://doi.org/10 $.2903 /$ j.efsa.2012.2554.

Falk, A. C., D. M. Weary, C. Winckler, and M. A. G. von Keyserlingk. 2012. Preference for pasture versus freestall housing by dairy cattle when stall availability indoors is reduced. J. Dairy Sci. 95:64096415. https://doi.org/10.3168/jds.2011-5208.

Fisher, A. D., M. A. Crowe, P. O'Kiely, and W. J. Enright. 1997. Growth, behaviour, adrenal and immune responses of finishing beef heifers housed on slatted floors at 1.5, 2.0, 2.5 or $3.0 \mathrm{~m}^{2}$ space allowance. Livest. Prod. Sci. 51:245-254. https://doi.org/10.1016/ S0301-6226(97)00052-3.

Fisher, A. D., N. Roberts, S. J. Bluett, G. A. Verkerk, and L. R. Matthews. 2008. Effects of shade provision on the behaviour, body temperature and milk production of grazing dairy cows during a New Zealand summer. N. Z. J. Agric. Res. 51:99-105. https://doi .org/10.1080/00288230809510439.

Fisher, A. D., M. Stewart, G. A. Verkerk, C. J. Morrow, and L. R. Matthews. 2003. The effects of surface type on lying behaviour and stress responses of dairy cows during periodic weather-induced removal from pasture. Appl. Anim. Behav. Sci. 81:1-11. https:// doi.org/10.1016/S0168-1591(02)00240-X.

Fisher, A. D., G. A. Verkerk, C. J. Morrow, and L. R. Matthews. 2002. The effects of feed restriction and lying deprivation on pituitaryadrenal axis regulation in lactating cows. Livest. Prod. Sci. 73:255263. https://doi.org/10.1016/S0301-6226(01)00246-9.

Fitzpatrick, C. E., N. Chapinal, C. S. Petersson-Wolfe, T. J. DeVries, D. F. Kelton, T. F. Duffield, and K. E. Leslie. 2013. The effect of meloxicam on pain sensitivity, rumination time, and clinical signs in dairy cows with endotoxin-induced clinical mastitis. J. Dairy Sci. 96:2847-2856. https://doi.org/10.3168/jds.2012-5855.

Flower, F. C., M. Sedlbauer, E. Carter, M. A. G. von Keyserlingk, D. J. Sanderson, and D. M. Weary. 2008. Analgesics improve the gait of lame dairy cattle. J. Dairy Sci. 91:3010-3014. https://doi.org/ 10.3168/jds.2007-0968.

Fogsgaard, K. K., T. W. Bennedsgaard, and M. S. Herskin. 2015. Behavioral changes in freestall-housed dairy cows with naturally occurring clinical mastitis. J. Dairy Sci. 98:1730-1738. https://doi .org/10.3168/jds.2014-8347.

Fogsgaard, K. K., C. M. Røntved, P. Sørensen, and M. S. Herskin. 2012. Sickness behavior in dairy cows during Escherichia coli mastitis. J. Dairy Sci. 95:630-638. https://doi.org/10.3168/jds.2011 -4350 .

Fraser, D. 2018. Animal welfare: Translating science into practice. In Advances in Agricultural Animal Welfare: Science and Practice. J. A. Mench, ed. Woodhead Publishing, Duxford, UK.

Fregonesi, J. A., and J. D. Leaver. 2001. Behaviour, performance and health indicators of welfare for dairy cows housed in strawyard or cubicle systems. Livest. Prod. Sci. 68:205-216. https://doi.org/10 .1016/S0301-6226(00)00234-7.

Fregonesi, J. A., and J. D. Leaver. 2002. Influence of space allowance and milk yield level on behaviour, performance and health of dairy cows housed in strawyard and cubicle systems. Livest. Prod. Sci. 78:245-257. https://doi.org/10.1016/S0301-6226(02)00097-0.

Fregonesi, J. A., C. B. Tucker, and D. M. Weary. 2007a. Overstocking reduces lying time in dairy cows. J. Dairy Sci. 90:3349-3354. https: //doi.org/10.3168/jds.2006-794.

Fregonesi, J. A., C. B. Tucker, D. M. Weary, F. C. Flower, and T. Vittie. 2004. Effect of rubber flooring in front of the feed bunk on the time budgets of dairy cattle. J. Dairy Sci. 87:1203-1207. https:// doi.org/10.3168/jds.S0022-0302(04)73270-1.

Fregonesi, J. A., D. M. Veira, M. A. G. von Keyserlingk, and D. M. Weary. 2007b. Effects of bedding quality on lying behavior of dairy cows. J. Dairy Sci. 90:5468-5472. https://doi.org/10.3168/jds.2007 -0494 .

Friend, T. H., F. G. Gwazdauskas, and C. E. Polan. 1979. Change in adrenal response from free stall competition. J. Dairy Sci. 62:768771. https://doi.org/10.3168/jds.S0022-0302(79)83321-4.

Friend, T. H., C. E. Polan, and M. L. McGilliard. 1977. Free stall and feed bunk requirements relative to behavior, production and individual feed intake in dairy cows. J. Dairy Sci. 60:108-116. https:/ /doi.org/10.3168/jds.S0022-0302(77)83835-6.

Fureix, C., and R. K. Meagher. 2015. What can inactivity (in its various forms) reveal about affective states in non-human animals? A review. Appl. Anim. Behav. Sci. 171:8-24. https://doi.org/10 .1016/j.applanim.2015.08.036.

Galindo, F., and D. M. Broom. 2000. The relationships between social behaviour of dairy cows and the occurrence of lameness in three herds. Res. Vet. Sci. 69:75-79. https://doi.org/10.1053/rvsc.2000 .0391 .

Gomez, A., and N. B. Cook. 2010. Time budgets of lactating dairy cattle in commercial freestall herds. J. Dairy Sci. 93:5772-5781. https://doi.org/10.3168/jds.2010-3436.

Gonyou, H. W., R. J. Christopherson, and B. A. Young. 1979. Effects of cold temperature and winter conditions on some aspects of behaviour of feedlot cattle. Appl. Anim. Ethol. 5:113-124. https:// doi.org/10.1016/0304-3762(79)90083-X.

González, M., A. K. Yabuta, and F. Galindo. 2003. Behaviour and adrenal activity of first parturition and multiparous cows under a competitive situation. Appl. Anim. Behav. Sci. 83:259-266. https: //doi.org/10.1016/S0168-1591(03)00037-6.

Gregorini, P., B. Dela Rue, M. Pourau, C. Glassey, and J. Jago. 2013. A note on rumination behavior of dairy cows under intensive grazing systems. Livest. Sci. 158:151-156. https://doi.org/10.1016/j .livsci.2013.10.012.

Gregorini, P., B. DelaRue, K. McLeod, C. E. F. Clark, C. B. Glassey, and J. Jago. 2012. Rumination behavior of grazing dairy cows in response to restricted time at pasture. Livest. Sci. 146:95-98. https://doi.org/10.1016/j.livsci.2012.02.020.

Gygax, L., R. Siegwart, and B. Wechsler. 2007. Effects of space allowance on the behaviour and cleanliness of finishing bulls kept in pens with fully slatted rubber coated flooring. Appl. Anim. Behav. Sci. 107:1-12. https://doi.org/10.1016/j.applanim.2006.09.011. 
Haley, D. B., A. M. de Passillé, and J. Rushen. 2001. Assessing cow comfort: Effects of two floor types and two tie stall designs on the behaviour of lactating dairy cows. Appl. Anim. Behav. Sci. 71:105-117. https://doi.org/10.1016/S0168-1591(00)00175-1.

Haley, D. B., J. Rushen, and A. M. de Passillé. 2000. Behavioural indicators of cow comfort: Activity and resting behaviour of dairy cows in two types of housing. Can. J. Anim. Sci. 80:257-263. https: //doi.org/10.4141/A99-084.

Hänninen, L., J. P. Mäkelä, J. Rushen, A. M. de Passillé, and H. Saloniemi. 2008. Assessing sleep state in calves through electrophysiological and behavioural recordings: A preliminary study. Appl. Anim. Behav. Sci. 111:235-250. https://doi.org/10.1016/j applanim.2007.06.009.

Hart, K. D., B. W. McBride, T. F. Duffield, and T. J. DeVries. 2013. Effect of milking frequency on the behavior and productivity of lactating dairy cows. J. Dairy Sci. 96:6973-6985. https://doi.org/ 10.3168/jds.2013-6764.

Hassall, S. A., W. R. Ward, and R. D. Murray. 1993. Effects of lameness on the behavior of cows during the summer. Vet. Rec. 132:578-580. https://doi.org/10.1136/vr.132.23.578.

Helmreich, S., R. Hauser, T. Jungbluth, B. Wechsler, and L. Gygax. 2014. Time-budget constraints for cows with high milking frequency on farms with automatic milking systems. Livest. Sci. 167:315322. https://doi.org/10.1016/j.livsci.2014.06.014.

Hendriks, S. J., C. V. C. Phyn, S. A. Turner, K. M. Mueller, B. KuhnSherlock, D. J. Donaghy, J. M. Huzzey, and J. R. Roche. 2019. Lying behavior and activity during the transition period of clinically healthy grazing dairy cows. J. Dairy Sci. 102:7371-7384. https:// doi.org/10.3168/jds.2018-16045.

Henriksen, J. C. S., M. R. Weisbjerg, P. Løvendahl, T. Kristensen, and L. Munksgaard. 2019. Effects of an individual cow concentrate strategy on production and behavior. J. Dairy Sci. 102:2155-2172. https://doi.org/10.3168/jds.2018-15477.

Hernandez-Mendo, O., M. A. G. von Keyserlingk, D. M. Veira, and D. M. Weary. 2007. Effects of pasture on lameness in dairy cows. J. Dairy Sci. 90:1209-1214. https://doi.org/10.3168/jds.S0022 -0302(07)71608-9.

Hetti Arachchige, A. D., A. D. Fisher, M. J. Auldist, W. J. Wales, and E. C. Jongman. 2013. Effects of different systems of feeding supplements on time budgets of cows grazing restricted pasture allowances. Appl. Anim. Behav. Sci. 148:13-20. https://doi.org/10 .1016/j.applanim.2013.08.002.

Hickey, M. C., B. Earley, and A. D. Fisher. 2003. The effect of floor type and space allowance on welfare indicators of finishing steers. Ir. J. Agric. Food Res. 42:89-100.

Hill, C. T., P. D. Krawczel, H. M. Dann, C. S. Ballard, R. C. Hovey, W. A. Falls, and R. J. Grant. 2009. Effect of stocking density on the short-term behavioural responses of dairy cows. Appl. Anim. Behav. Sci. 117:144-149. https://doi.org/10.1016/j.applanim.2008 .12 .012 .

Hindhede, J., J. T. Sørensen, M. B. Jensen, and C. C. Krohn. 1996. Effect of space allowance, access to bedding, and flock size in slatted floor systems on the production and health of dairy heifers. Acta Agric. Scand. A Anim. Sci. 46:46-53. https://doi.org/10.1080/ 09064709609410923.

Hoenig, D. E., and J. F. Coetzee. 2018. Perspectives on the emerging role of US veterinarians in education, policy, politics, and research. In Advances in Agricultural Animal Welfare: Science and Practice. J. A. Mench, ed. Woodhead Publishing, Duxford, UK.

Hovland, A. L., G. Mason, K. E. Bøe, G. Steinheim, and M. Bakken. 2006. Evaluation of the 'maximum price paid' as an index of motivational strength for farmed silver foxes (Vulpes vulpes). Appl. Anim. Behav. Sci. 100:258-279. https://doi.org/10.1016/j .applanim.2005.11.006.

Huzzey, J. M., T. J. DeVries, P. Valois, and M. A. G. von Keyserlingk. 2006. Stocking density and feed barrier design affect the feeding and social behavior of dairy cattle. J. Dairy Sci. 89:126-133. https: //doi.org/10.3168/jds.S0022-0302(06)72075-6.

Huzzey, J. M., M. A. G. Von Keyserlingk, and D. M. Weary. 2005. Changes in feeding, drinking, and standing behavior of dairy cows during the transition period. J. Dairy Sci. 88:2454-2461. https:// doi.org/10.3168/jds.S0022-0302(05)72923-4.

Itle, A. J., J. M. Huzzey, D. M. Weary, and M. A. G. von Keyserlingk. 2015. Clinical ketosis and standing behavior in transition cows. J. Dairy Sci. 98:128-134. https://doi.org/10.3168/jds.2014-7932.

Ito, K., N. Chapinal, D. M. Weary, and M. A. G. von Keyserlingk. 2014. Associations between herd-level factors and lying behavior of freestall-housed dairy cows. J. Dairy Sci. 97:2081-2089. https:/ /doi.org/10.3168/jds.2013-6861.

Ito, K., M. A. G. von Keyserlingk, S. J. LeBlanc, and D. M. Weary. 2010. Lying behavior as an indicator of lameness in dairy cows. J. Dairy Sci. 93:3553-3560. https://doi.org/10.3168/jds.2009-2951.

Ito, K., D. M. Weary, and M. A. G. von Keyserlingk. 2009. Lying behavior: Assessing within- and between-herd variation in free-stallhoused dairy cows. J. Dairy Sci. 92:4412-4420. https://doi.org/10 $.3168 /$ jds.2009-2235.

Jensen, M. B. 2011. The early behaviour of cow and calf in an individual calving pen. Appl. Anim. Behav. Sci. 134:92-99. https://doi .org/10.1016/j.applanim.2011.06.017.

Jensen, M. B., L. Munksgaard, L. J. Pedersen, J. Ladewig, and L. Matthews. 2004. Prior deprivation and reward duration affect the demand function for rest in dairy heifers. Appl. Anim. Behav. Sci. 88:1-11. https://doi.org/10.1016/j.applanim.2004.02.019.

Jensen, M. B., and L. J. Pedersen. 2008. Using motivation tests to assess ethological needs and preferences. Appl. Anim. Behav. Sci. 113:340-356. https://doi.org/10.1016/j.applanim.2008.02.001.

Jensen, M. B., L. J. Pedersen, and L. Munksgaard. 2005. The effect of reward duration on demand functions for rest in dairy heifers and lying requirements as measured by demand functions. Appl. Anim. Behav. Sci. 90:207-217. https://doi.org/10.1016/j.applanim 2004.08.006.

Jónsson, R., M. Blanke, N. K. Poulsen, F. Caponetti, and S. Højsgaard. 2011. Oestrus detection in dairy cows from activity and lying data using on-line individual models. Comput. Electron. Agric. 76:6-15. https://doi.org/10.1016/j.compag.2010.12.014.

Kanjanapruthipong, J., W. Junlapho, and K. Karnjanasirm. 2015. Feeding and lying behavior of heat-stressed early lactation cows fed low fiber diets containing roughage and nonforage fiber sources. J. Dairy Sci. 98:1110-1118. https://doi.org/10.3168/jds.2014 -8154 .

Kendall, P. E., P. P. Nielsen, J. R. Webster, G. A. Verkerk, R. P. Littlejohn, and L. R. Matthews. 2006. The effects of providing shade to lactating dairy cows in a temperate climate. Livest. Sci. 103:148-157. https://doi.org/10.1016/j.livsci.2006.02.004.

Ketelaar-de Lauwere, C. C., A. H. Ipema, E. N. J. van Ouwerkerk, M. M. W. B. Hendriks, J. H. M. Metz, J. P. T. M. Noordhuizen, and W. G. P. Schouten. 1999. Voluntary automatic milking in combination with grazing of dairy cows: Milking frequency and effects on behaviour. Appl. Anim. Behav. Sci. 64:91-109. https://doi.org/ 10.1016/S0168-1591(99)00027-1.

Kilgour, R. J. 2012. In pursuit of "normal": A review of the behaviour of cattle at pasture. Appl. Anim. Behav. Sci. 138:1-11. https://doi .org/10.1016/j.applanim.2011.12.002.

King, M. T. M., E. A. Pajor, S. J. LeBlanc, and T. J. DeVries. 2016. Associations of herd-level housing, management, and lameness prevalence with productivity and cow behavior in herds with automated milking systems. J. Dairy Sci. 99:9069-9079. https://doi .org/10.3168/jds.2016-11329.

Kirkden, R. D., J. S. S. Edwards, and D. M. Broom. 2003. A theoretical comparison of the consumer surplus and the elasticities of demand as measures of motivational strength. Anim. Behav. 65:157-178. https://doi.org/10.1006/anbe.2002.2035.

Kok, A., A. T. M. van Knegsel, C. E. van Middelaar, H. Hogeveen, B. Kemp, and I. J. M. de Boer. 2015. Technical note: Validation of sensor-recorded lying bouts in lactating dairy cows using a 2-sensor approach. J. Dairy Sci. 98:7911-7916. https://doi.org/10.3168/ jds.2015-9554.

Krawczel, P. D., L. B. Klaiber, R. E. Butzler, L. M. Klaiber, H. M. Dann, C. S. Mooney, and R. J. Grant. 2012a. Short-term increases in stocking density affect the lying and social behavior, but not 
the productivity, of lactating Holstein dairy cows. J. Dairy Sci. 95:4298-4308. https://doi.org/10.3168/jds.2011-4687.

Krawczel, P. D., and A. R. Lee. 2019. Lying time and its importance to the dairy cow impact of stocking density and time budget stresses. Vet. Clin. North Am. Food Anim. Pract. 35:47-60. https://doi .org/10.1016/j.cvfa.2018.11.002.

Krawczel, P. D., C. S. Mooney, H. M. Dann, M. P. Carter, R. E. Butzler, C. S. Ballard, and R. J. Grant. 2012b. Effect of alternative models for increasing stocking density on the short-term behavior and hygiene of Holstein dairy cows. J. Dairy Sci. 95:2467-2475. https://doi.org/10.3168/jds.2011-4686.

Krebs, N., S. L. Berry, and C. B. Tucker. 2011. Restless behavior increases over time, but not with compressibility of the flooring surface, during forced standing at the feed bunk. J. Dairy Sci. 94:97-105. https://doi.org/10.3168/jds.2010-3089.

Krohn, C. C. 1994. Behaviour of dairy cows kept in extensive (loose housing/pasture) or intensive (tie stall) environments. III. Grooming, exploration and abnormal behaviour. Appl. Anim. Behav. Sci. 42:73-86. https://doi.org/10.1016/0168-1591(94)90148-1.

Krohn, C. C., and L. Munksgaard. 1993. Behaviour of dairy cows kept in extensive (loose housing/pasture) or intensive (tie stall) environments II. Lying and lying-down behaviour. Appl. Anim. Behav. Sci. 37:1-16. https://doi.org/10.1016/0168-1591(93)90066-X.

Kull, J. A., K. L. Proudfoot, G. M. Pighetti, J. M. Bewley, B. F. O'Hara, K. D. Donohue, and P. D. Krawczel. 2019. Effects of acute lying and sleep deprivation on the behavior of lactating dairy cows. PLoS One 14:e0212823. https://doi.org/10.1371/journal.pone .0212823

Leach, K. A., J. E. Offer, I. Svoboda, and D. N. Logue. 2005. Effects of type of forage fed to dairy heifers: Associations between claw characteristics, clinical lameness, environment and behaviour. Vet. J. 169:427-436. https://doi.org/10.1016/j.tvjl.2004.03.023.

Ledgerwood, D. N., C. Winckler, and C. B. Tucker. 2010. Evaluation of data loggers, sampling intervals, and editing techniques for measuring the lying behavior of dairy cattle. J. Dairy Sci. 93:51295139. https://doi.org/10.3168/jds.2009-2945.

Legrand, A., K. E. Schütz, and C. B. Tucker. 2011. Using water to cool cattle: Behavioral and physiological changes associated with voluntary use of cow showers. J. Dairy Sci. 94:3376-3386. https:// doi.org/10.3168/jds.2010-3901.

Legrand, A. L., M. A. G. von Keyserlingk, and D. M. Weary. 2009. Preference and usage of pasture versus free-stall housing by lactating dairy cattle. J. Dairy Sci. 92:3651-3658. https://doi.org/10 $.3168 /$ jds.2008-1733.

Leonard, F. C., J. O'Connell, and K. O'Farrell. 1994. Effect of different housing conditions on behaviour and foot lesions in Friesian heifers. Vet. Rec. 134:490-494. https://doi.org/10.1136/vr.134.19 490.

Leonard, F. C., J. M. O'Connell, and K. J. O'Farrell. 1996. Effect of overcrowding on claw health in first-calved Friesian heifers. Br. Vet. J. 152:459-472. https://doi.org/10.1016/S0007-1935(96)80040-6.

Lidfors, L. 1989. The use of getting up and lying down movements in the evaluation of cattle environments. Vet. Res. Commun. 13:307324. https://doi.org/10.1007/BF00420838.

Lobeck-Luchterhand, K. M., P. R. B. Silva, R. C. Chebel, and M. I. Endres. 2015. Effect of stocking density on social, feeding, and lying behavior of prepartum dairy animals. J. Dairy Sci. 98:240-249. https://doi.org/10.3168/jds.2014-8492

Løvendahl, P., and L. Munksgaard. 2016. An investigation into genetic and phenotypic variation in time budgets and yield of dairy cows. J. Dairy Sci. 99:408-417. https://doi.org/10.3168/jds.2015-9838.

Malechek, J. C., and B. M. Smith. 1976. Behavior of range cows in response to winter weather. J. Range Manage. 29:9-12. https://doi .org/10.2307/3897679.

Manninen, E., A. M. de Passillé, J. Rushen, M. Norring, and H. Saloniemi. 2002. Preferences of dairy cows kept in unheated buildings for different kind of cubicle flooring. Appl. Anim. Behav. Sci. 75:281-292. https://doi.org/10.1016/S0168-1591(01)00206-4.

Maselyne, J., M. Pastell, P. T. Thomsen, V. M. Thorup, L. Hänninen, J. Vangeyte, A. Van Nuffel, and L. Munksgaard. 2017. Daily lying time, motion index and step frequency in dairy cows change throughout lactation. Res. Vet. Sci. 110:1-3. https://doi.org/10 .1016 /j.rvsc.2016.10.003.

Mattachini, G., L. Bava, A. Sandrucci, A. Tamburini, E. Riva, and G. Provolo. 2017. Effects of feed delivery frequency in different environmental conditions on time budget of lactating dairy cows. J. Dairy Res. 84:272-279. https://doi.org/10.1017/S0022029917000310.

Matthews, L. R., C. Cameron, A. J. Sheahan, E. S. Kolver, and J. R. Roche. 2012. Associations among dairy cow body condition and welfare-associated behavioral traits. J. Dairy Sci. 95:2595-2601. https://doi.org/10.3168/jds.2011-4889.

Meagher, R. K. 2019. Is boredom an animal welfare concern? Anim. Welf. 28:21-32. https://doi.org/10.7120/09627286.28.1.021.

Medrano-Galarza, C., J. Gibbons, S. Wagner, A. M. de Passillé, and J. Rushen. 2012. Behavioral changes in dairy cows with mastitis. J. Dairy Sci. 95:6994-7002. https://doi.org/10.3168/jds.2011-5247.

Metz, J. H. M. 1985. The reaction of cows to a short-term deprivation of lying. Appl. Anim. Behav. Sci. 13:301-307. https://doi.org/10 .1016/0168-1591(85)90010-3.

Miedema, H. M., M. S. Cockram, C. M. Dwyer, and A. I. Macrae. 2011. Changes in the behaviour of dairy cows during the $24 \mathrm{~h}$ before normal calving compared with behaviour during late pregnancy. Appl. Anim. Behav. Sci. 131:8-14. https://doi.org/10.1016/ j.applanim.2011.01.012.

Ministry for Primary Industries. 2019. Codes of Welfare. Accessed May 25, 2020. https://www.mpi.govt.nz/protection-and-response/ animal-welfare/codes-of-welfare/.

Morabito, E., H. W. Barkema, E. A. Pajor, L. Solano, D. Pellerin, and K. Orsel. 2017. Effects of changing freestall area on lameness, lying time, and leg injuries on dairy farms in Alberta, Canada. J. Dairy Sci. 100:6516-6526. https://doi.org/10.3168/jds.2016-12467.

Müller, C., J. Ladewig, H. H. Thielscher, and D. Smidt. 1989. Behavior and heart-rate of heifers housed in tether stanchions without straw. Physiol. Behav. 46:751-754. https://doi.org/10.1016/0031 -9384(89)90362-4.

Munksgaard, L., M. S. Herskin, P. Løvendahl, and J. B. Andersen. 2006. Effects of nutrition on stress reactivity. In Ruminant Physiology: Digestion, Metabolism and Impact of Nutrition on Gene Expression, Immunology and Stress. K. Sejrsen, T. Hvelplund, and M. O. Nielsen, ed. Wageningen Academic Publishers, Wageningen, the Netherlands.

Munksgaard, L., K. L. Ingvartsen, L. J. Pedersen, and V. K. M. Nielsen. 1999. Deprivation of lying down affects behaviour and pituitaryadrenal axis responses in young bulls. Acta Agric. Scand. A Anim. Sci. 49:172-178. https://doi.org/10.1080/090647099424088.

Munksgaard, L., M. B. Jensen, L. J. Pedersen, S. W. Hansen, and L. Matthews. 2005. Quantifying behavioural priorities - Effects of time constraints on behaviour of dairy cows, Bos taurus. Appl. Anim. Behav. Sci. 92:3-14. https://doi.org/10.1016/j.applanim .2004.11.005.

Munksgaard, L., and P. Løvendahl. 1993. Effects of social and physical stressors on growth hormone levels in dairy cows. Can. J. Anim. Sci. 73:847-853. https://doi.org/10.4141/cjas93-087.

Munksgaard, L., J. Rushen, A. M. de Passillé, and C. C. Krohn. 2011. Forced versus free traffic in an automated milking system. Livest. Sci. 138:244-250. https://doi.org/10.1016/j.livsci.2010.12.023.

Munksgaard, L., and H. B. Simonsen. 1996. Behavioral and pituitary adrenal-axis responses of dairy cows to social isolation and deprivation of lying down. J. Anim. Sci. 74:769-778. https://doi.org/10 $.2527 / 1996.744769 x$.

Munksgaard, L., M. R. Weisbjerg, J. C. S. Henriksen, and P. Løvendahl. 2020. Changes to steps, lying, and eating behavior during lactation in Jersey and Holstein cows and the relationship to feed intake, yield, and weight. J. Dairy Sci. 103:4643-4653. https://doi .org/10.3168/jds.2019-17565.

National Farm Animal Care Council. 2009. Code of Practice for the Care and Handling of Dairy Cattle. Accessed Nov. 20, 2019. http:/ /www.nfacc.ca/pdfs/codes/dairy_code_of_practice.pdf.

Navarro, G., L. E. Green, and N. Tadich. 2013. Effect of lameness and lesion specific causes of lameness on time budgets of dairy cows at pasture and when housed. Vet. J. 197:788-793. https://doi.org/10 $.1016 /$ j.tvjl.2013.05.012. 
Neveux, S., D. M. Weary, J. Rushen, M. A. G. von Keyserlingk, and A. M. de Passillé. 2006. Hoof discomfort changes how dairy cattle distribute their body weight. J. Dairy Sci. 89:2503-2509. https:// doi.org/10.3168/jds.S0022-0302(06)72325-6.

Nielsen, B. L., R. F. Veerkamp, and A. B. Lawrence. 2000. Effects of genotype, feed type and lactational stage on the time budget of dairy cows. Acta Agric. Scand. A Anim. Sci. 50:272-278. https:// doi.org/10.1080/090647000750069467.

Nielsen, L. H., L. Mogensen, C. Krohn, J. Hindhede, and J. T. S $\varnothing-$ rensen. 1997. Resting and social behaviour of dairy heifers housed in slatted floor pens with different sized bedded lying areas. Appl. Anim. Behav. Sci. 54:307-316. https://doi.org/10.1016/S0168 $-1591(96) 01211-7$.

Nordlund, K. V., P. Strassburg, T. B. Bennett, G. R. Oetzel, and N. B. Cook. 2019. Thermodynamics of standing and lying behavior in lactating dairy cows in freestall and parlor holding pens during conditions of heat stress. J. Dairy Sci. 102:6495-6507. https://doi .org/10.3168/jds.2018-15891.

Norring, M., E. Manninen, A. M. de Passillé, J. Rushen, L. Munksgaard, and H. Saloniemi. 2008. Effects of sand and straw bedding on the lying behavior, cleanliness, and hoof and hock injuries of dairy cows. J. Dairy Sci. 91:570-576. https://doi.org/10.3168/jds 2007-0452.

Norring, M., and A. Valros. 2016. The effect of lying motivation on cow behaviour. Appl. Anim. Behav. Sci. 176:1-5. https://doi.org/ 10.1016/j.applanim.2015.11.022.

Norring, M., A. Valros, and L. Munksgaard. 2012. Milk yield affects time budget of dairy cows in tie-stalls. J. Dairy Sci. 95:102-108. https://doi.org/10.3168/jds.2010-3458.

O'Connell, J., P. S. Giller, and W. Meaney. 1989. A comparison of dairy cattle behavioural patterns at pasture and during confinement. Isr. J. Agric. Res. 28:65-72.

O'Connor, C., S. Dowling, V. Cave, and J. Webster. 2019. Cow lying behaviour and bedding quality changes during five weeks on a stand-off pad. Animals (Basel) 9:257. https://doi.org/10.3390/ ani9050257.

O'Driscoll, K., L. Boyle, and A. Hanlon. 2008. A brief note on the validation of a system for recording lying behaviour in dairy cows. Appl. Anim. Behav. Sci. 111:195-200. https://doi.org/10.1016/j .applanim.2007.05.014.

O'Driscoll, K., L. Boyle, and A. Hanlon. 2009. The effect of breed and housing system on dairy cow feeding and lying behaviour. Appl. Anim. Behav. Sci. 116:156-162. https://doi.org/10.1016/j applanim.2008.08.003.

O'Driscoll, K., D. Gleeson, B. O'Brien, and L. Boyle. 2010a. Effect of milking frequency and nutritional level on hoof health, locomotion score and lying behaviour of dairy cows. Livest. Sci. 127:248-256. https://doi.org/10.1016/j.livsci.2009.10.006.

O'Driscoll, K., D. Gleeson, B. O'Brien, and L. Boyle. 2011. Does omission of a regular milking event affect cow comfort? Livest. Sci. 138:132-143. https://doi.org/10.1016/j.livsci.2010.12.013.

O'Driscoll, K., E. Lewis, and E. Kennedy. 2019. Effect of feed allowance at pasture on the lying behaviour of dairy cows. Appl. Anim. Behav. Sci. 213:40-46. https://doi.org/10.1016/j.applanim.2019.02 .002 .

O'Driscoll, K., B. O'Brien, D. Gleeson, and L. Boyle. 2010b. Milking frequency and nutritional level affect grazing behaviour of dairy cows: A case study. Appl. Anim. Behav. Sci. 122:77-83. https:// doi.org/10.1016/j.applanim.2009.11.014.

OIE. 2019. Animal Welfare and Dairy Cattle Production Systems in the Terrestrial Animal Health Code. Accessed May 27, 2020. https: //www.oie.int/fileadmin/Home/eng/Health_standards/tahc/ current/chapitre_aw_dairy_cattle.pdf.

Olmos, G., L. Boyle, A. Hanlon, J. Patton, J. J. Murphy, and J. F. Mee. 2009. Hoof disorders, locomotion ability and lying times of cubicle-housed compared to pasture-based dairy cows. Livest. Sci. 125:199-207. https://doi.org/10.1016/j.livsci.2009.04.009.

Olofsson, J., and H. Wiktorsson. 2001. Competition for total mixed diets fed restrictively using one or four cows per feeding station. Acta Agric. Scand. A Anim. Sci. 51:59-70. https://doi.org/10 $.1080 / 090647001300004808$.
Olson, B. E., and R. T. Wallander. 2002. Influence of winter weather and shelter on activity patterns of beef cows. Can. J. Anim. Sci. 82:491-501. https://doi.org/10.4141/A01-070.

Österman, S., and I. Redbo. 2001. Effects of milking frequency on lying down and getting up behaviour in dairy cows. Appl. Anim. Behav. Sci. 70:167-176. https://doi.org/10.1016/S0168-1591(00)00159-3.

Overton, M. W., W. M. Sischo, G. D. Temple, and D. A. Moore. 2002. Using time-lapse video photography to assess dairy cattle lying behavior in a free-stall barn. J. Dairy Sci. 85:2407-2413. https:// doi.org/10.3168/jds.S0022-0302(02)74323-3.

Piñeiro, J. M., B. T. Menichetti, A. A. Barragan, A. E. Relling, W. P. Weiss, S. Bas, and G. M. Schuenemann. 2019. Associations of postpartum lying time with culling, milk yield, cyclicity, and reproductive performance of lactating dairy cows. J. Dairy Sci. 102:3362-3375. https://doi.org/10.3168/jds.2018-15387.

Plesch, G., N. Broerkens, S. Laister, C. Winckler, and U. Knierim. 2010. Reliability and feasibility of selected measures concerning resting behaviour for the on-farm welfare assessment in dairy cows. Appl. Anim. Behav. Sci. 126:19-26. https://doi.org/10.1016/j applanim.2010.05.003.

Proudfoot, K. L., D. M. Weary, and M. A. G. von Keyserlingk. 2010. Behavior during transition differs for cows diagnosed with claw horn lesions in mid lactation. J. Dairy Sci. 93:3970-3978. https:// doi.org/10.3168/jds.2009-2767.

Radoń, J., W. Bieda, J. Lendelová, and Š. Pogran. 2014. Computational model of heat exchange between dairy cow and bedding. Comput. Electron. Agric. 107:29-37. https://doi.org/10.1016/j .compag.2014.06.006.

Rajala-Schultz, P. J., P. N. Gott, K. L. Proudfoot, and M. Schuenemann. 2018. Effect of milk cessation method at dry-off on behavioral activity of dairy cows. J. Dairy Sci. 101:3261-3270. https:// doi.org/10.3168/jds.2017-13588.

Rajapaksha, E., and C. B. Tucker. 2014. How do cattle respond to sloped floors? An investigation using behavior and electromyograms. J. Dairy Sci. 97:2808-2815. https://doi.org/10.3168/jds .2013-7435.

Rajapaksha, E., and C. B. Tucker. 2015. Stepping behavior and muscle activity of dairy cows on uncomfortable standing surfaces presented under 1 or 4 legs. J. Dairy Sci. 98:295-304. https://doi.org/10 $.3168 /$ jds.2014-8652.

Rajapaksha, E., C. Winkler, and C. B. Tucker. 2015. Effect of rubber flooring on dairy cattle stepping behavior and muscle activity. J. Dairy Sci. 98:2462-2471. https://doi.org/10.3168/jds.2014-8930.

Redbo, I., I. Mossberg, A. Ehrlemark, and M. Ståhl-Högberg. 1996. Keeping growing cattle outside during winter: Behaviour, production and climatic demand. Anim. Sci. 62:35-41. https://doi.org/10 $.1017 /$ S1357729800014284.

Reich, L. J., D. M. Weary, D. M. Veira, and M. A. G. von Keyserlingk. 2010. Effects of sawdust bedding dry matter on lying behavior of dairy cows: A dose-dependent response. J. Dairy Sci. 93:15611565. https://doi.org/10.3168/jds.2009-2713.

Reith, S., and S. Hoy. 2012. Relationship between daily rumination time and estrus of dairy cows. J. Dairy Sci. 95:6416-6420. https:/ /doi.org/10.3168/jds.2012-5316.

Rouha-Mülleder, C., C. Iben, E. Wagner, G. Laaha, J. Troxler, and S. Waiblinger. 2009. Relative importance of factors influencing the prevalence of lameness in Austrian cubicle loose-housed dairy cows. Prev. Vet. Med. 92:123-133. https://doi.org/10.1016/ j.prevetmed.2009.07.008.

Ruckebusch, Y. 1972. The relevance of drowsiness in the circadian cycle of farm animals. Anim. Behav. 20:637-643. https://doi.org/ 10.1016/S0003-3472(72)80136-2.

Ruckebusch, Y. 1974. Sleep deprivation in cattle. Brain Res. 78:495499. https://doi.org/10.1016/0006-8993(74)90932-9.

Ruckebusch, Y. 1975. Feeding and sleep patterns of cows prior to and post parturition. Appl. Anim. Ethol. 1:283-292. https://doi.org/ 10.1016/0304-3762(75)90021-8.

Rushen, J., N. Chapinal, and A. M. de Passillé. 2012. Automated monitoring of behavioural-based animal welfare indicators. Anim. Welf. 21:339-350. https://doi.org/10.7120/09627286.21.3.339. 
Rushen, J., D. Haley, and A. M. de Passillé. 2007. Effect of softer flooring in tie stalls on resting behavior and leg injuries of lactating cows. J. Dairy Sci. 90:3647-3651. https://doi.org/10.3168/jds 2006-463.

Schirmann, K., N. Chapinal, D. M. Weary, W. Heuwieser, and M. A. G. von Keyserlingk. 2011. Short-term effects of regrouping on behavior of prepartum dairy cows. J. Dairy Sci. 94:2312-2319. https: //doi.org/10.3168/jds.2010-3639.

Schirmann, K., N. Chapinal, D. M. Weary, W. Heuwieser, and M. A. G. von Keyserlingk. 2012. Rumination and its relationship to feeding and lying behavior in Holstein dairy cows. J. Dairy Sci. 95:3212-3217. https://doi.org/10.3168/jds.2011-4741.

Schütz, K. E., V. M. Cave, N. R. Cox, F. J. Huddart, and C. B. Tucker. 2019. Effects of 3 surface types on dairy cattle behavior, preference, and hygiene. J. Dairy Sci. 102:1530-1541. https://doi .org/10.3168/jds.2018-14792.

Schütz, K. E., K. V. Clark, N. R. Cox, L. R. Matthews, and C. B. Tucker. 2010a. Responses to short-term exposure to simulated rain and wind by dairy cattle: Time budgets, shelter use, body temperature and feed intake. Anim. Welf. 19:375-383.

Schütz, K. E., and N. R. Cox. 2014. Effects of short-term repeated exposure to different flooring surfaces on the behavior and physiology of dairy cattle. J. Dairy Sci. 97:2753-2762. https://doi.org/10 $.3168 /$ jds.2013-7310.

Schütz, K. E., N. R. Cox, K. A. Macdonald, J. R. Roche, G. A Verkerk, A. R. Rogers, C. B. Tucker, L. R. Matthews, S. Meier, and J. R. Webster. 2013. Behavioral and physiological effects of a short-term feed restriction in lactating dairy cattle with different body condition scores at calving. J. Dairy Sci. 96:4465-4476. https: //doi.org/10.3168/jds.2012-6507.

Schütz, K. E., F. J. Huddart, and V. M. Cave. 2020. Do dairy cattle use a woodchip bedded area to rest on when managed on pasture in summer? Appl. Anim. Behav. Sci. 223:104922. https://doi.org/ 10.1016/j.applanim.2019.104922.

Schütz, K. E., F. J. Huddart, M. A. Sutherland, M. Stewart, and N. R. Cox. 2015. Effects of space allowance on the behavior and physiology of cattle temporarily managed on rubber mats. J. Dairy Sci. 98:6226-6235. https://doi.org/10.3168/jds.2015-9593.

Schütz, K. E., E. Rajapaksha, E. M. Mintline, N. R. Cox, and C. B. Tucker. 2018. Stepping behavior and muscle activity of dairy cattle standing on concrete or rubber flooring for 1 or 3 hours. J. Dairy Sci. 101:9472-9482. https://doi.org/10.3168/jds.2018-14607.

Schütz, K. E., A. R. Rogers, Y. A. Poulouin, N. R. Cox, and C. B. Tucker. 2010b. The amount of shade influences the behavior and physiology of dairy cattle. J. Dairy Sci. 93:125-133. https://doi .org/10.3168/jds.2009-2416.

Sepúlveda-Varas, P., D. M. Weary, and M. A. G. von Keyserlingk. 2014. Lying behavior and postpartum health status in grazing dairy cows. J. Dairy Sci. 97:6334-6343. https://doi.org/10.3168/ jds.2014-8357.

Shultz, T. A. 1984. Weather and shade effects on cow corral activities. J. Dairy Sci. 67:868-873. https://doi.org/10.3168/jds.S0022 -0302(84)81379-X.

Siivonen, J., S. Taponen, M. Hovinen, M. Pastell, B. J. Lensink, S. Pyörälä, and L. Hänninen. 2011b. Impact of acute clinical mastitis on cow behaviour. Appl. Anim. Behav. Sci. 132:101-106. https:// doi.org/10.1016/j.applanim.2011.04.005.

Siivonen, J., S. Taponen, M. Hovinen, M. Pastell, B. J. Lensink, S. Pyörälä, and L. Hänninen. 2011a. Impact of acute clinical mastitis on cow behaviour. Appl. Anim. Behav. Sci. 132:101-106. https:// doi.org/10.1016/j.applanim.2011.04.005.

Silper, B. F., A. M. L. Madureira, L. B. Polsky, S. Soriano, A. F. Sica, J. L. M. Vasconcelos, and R. L. A. Cerri. 2017. Daily lying behavior of lactating Holstein cows during an estrus synchronization protocol and its associations with fertility. J. Dairy Sci. 100:8484-8495. https://doi.org/10.3168/jds.2016-12160.

Silper, B. F., L. Polsky, J. Luu, T. A. Burnett, J. Rushen, A. M. de Passillé, and R. L. A. Cerri. 2015. Automated and visual measurements of estrous behavior and their sources of variation in Holstein heifers. II: Standing and lying patterns. Theriogenology 84:333-341. https://doi.org/10.1016/j.theriogenology.2014.12.030.
Singh, S. S., W. R. Ward, K. Lautenbach, and R. D. Murray. 1993. Behavior of lame and normal dairy cows in cubicles and in a straw yard. Vet. Rec. 133:204-208. https://doi.org/10.1136/vr.133.9.204. Smid, A. M. C., E. E. A. Burgers, D. M. Weary, E. A. M. Bokkers, and M. A. G. von Keyserlingk. 2019. Dairy cow preference for access to an outdoor pack in summer and winter. J. Dairy Sci. 102:1551-1558. https://doi.org/10.3168/jds.2018-15007.

Solano, L., H. W. Barkema, E. A. Pajor, S. Mason, S. J. LeBlanc, C. G. R. Nash, D. B. Haley, D. Pellerin, J. Rushen, A. M. de Passillé, E. Vasseur, and K. Orsel. 2016. Associations between lying behavior and lameness in Canadian Holstein-Friesian cows housed in freestall barns. J. Dairy Sci. 99:2086-2101. https://doi.org/10 $.3168 /$ jds.2015-10336.

Sørensen, J. T., T. Rousing, S. H. Møller, M. Bonde, and L. Hegelund. 2007. On-farm welfare assessment systems: What are the recording costs? Anim. Welf. 16:237-239.

Steensels, M., C. Bahr, D. Berckmans, I. Halachmi, A. Antler, and E. Maltz. 2012. Lying patterns of high producing healthy dairy cows after calving in commercial herds as affected by age, environmental conditions and production. Appl. Anim. Behav. Sci. 136:88-95. https://doi.org/10.1016/j.applanim.2011.12.008.

Stefanowska, J., M. Plavsic, A. H. Ipema, and M. M. W. B. Hendriks. 2000. The effect of omitted milking on the behaviour of cows in the context of cluster attachment failure during automatic milking. Appl. Anim. Behav. Sci. 67:277-291. https://doi.org/10.1016/ S0168-1591(00)00087-3.

Stone, A. E., B. W. Jones, C. A. Becker, and J. M. Bewley. 2017. Influence of breed, milk yield, and temperature-humidity index on dairy cow lying time, neck activity, reticulorumen temperature, and rumination behavior. J. Dairy Sci. 100:2395-2403. https://doi .org/10.3168/jds.2016-11607.

Tapkı, I., and A. Şahin. 2006. Comparison of the thermoregulatory behaviours of low and high producing dairy cows in a hot environment. Appl. Anim. Behav. Sci. 99:1-11. https://doi.org/10.1016/j applanim.2005.10.003.

Telezhenko, E., M. A. G. von Keyserlingk, A. Talebi, and D. M. Weary. 2012. Effect of pen size, group size, and stocking density on activity in freestall-housed dairy cows. J. Dairy Sci. 95:3064-3069. https://doi.org/10.3168/jds.2011-4953.

Ternman, E., L. Hänninen, M. Pastell, S. Agenäs, and P. P. Nielsen. 2012. Sleep in dairy cows recorded with a non-invasive EEG technique. Appl. Anim. Behav. Sci. 140:25-32. https://doi.org/10 .1016/j.applanim.2012.05.005.

Ternman, E., E. Nilsson, P. P. Nielsen, M. Pastell, L. Hänninen, and S. Agenäs. 2019. Rapid eye movement sleep time in dairy cows changes during the lactation cycle. J. Dairy Sci. 102:5458-5465. https://doi.org/10.3168/jds.2018-15950.

Ternman, E., M. Pastell, S. Agenäs, C. Strasser, C. Winckler, P. P. Nielsen, and L. Hänninen. 2014. Agreement between different sleep states and behaviour indicators in dairy cows. Appl. Anim. Behav. Sci. 160:12-18. https://doi.org/10.1016/j.applanim.2014.08.014.

Ternman, E., M. Pastell, L. Hänninen, S. Agenäs, and P. P. Nielsen. 2018. First-night effect on sleep time in dairy cows. PLoS One 13:e0195593. https://doi.org/10.1371/journal.pone.0195593.

Thompson, A. J., D. M. Weary, J. A. Bran, R. R. Daros, M. J. Hotzel, and M. A. G. von Keyserlingk. 2019. Lameness and lying behavior in grazing dairy cows. J. Dairy Sci. 102:6373-6382. https://doi .org/10.3168/jds.2018-15717.

Thompson, A. J., D. M. Weary, and M. A. G. von Keyserlingk. 2017. Technical note: Mining data from on-farm electronic equipment to identify the time dairy cows spend away from the pen. J. Dairy Sci. 100:3975-3982. https://doi.org/10.3168/jds.2016-11713.

Thomsen, P. T., L. Munksgaard, and J. T. Sørensen. 2012. Locomotion scores and lying behaviour are indicators of hoof lesions in dairy cows. Vet. J. 193:644-647. https://doi.org/10.1016/j.tvjl .2012.06.046.

Thorne, P. L., J. G. Jago, E. S. Kolver, and J. R. Roche. 2003. Diet and genotype affect feeding behaviour of Holstein-Friesian dairy cows during late lactation. Proc. N.Z. Soc. Anim. Prod. 63:124127. 
Thorup, V. M., L. Munksgaard, P. E. Robert, H. W. Erhard, P. T. Thomsen, and N. C. Friggens. 2015. Lameness detection via legmounted accelerometers on dairy cows on four commercial farms. Animal 9:1704-1712. https://doi.org/10.1017/S1751731115000890.

Tolkamp, B. J., M. J. Haskell, F. M. Langford, D. J. Roberts, and C. A. Morgan. 2010. Are cows more likely to lie down the longer they stand? Appl. Anim. Behav. Sci. 124:1-10. https://doi.org/10 .1016/j.applanim.2010.02.004.

Tresoldi, G., K. E. Schütz, and C. B. Tucker. 2017. Cow cooling on commercial drylot dairies: A description of 10 farms in California. Calif. Agric. 71:249-255. https://doi.org/10.3733/ca.2017a0042.

Tresoldi, G., K. E. Schütz, and C. B. Tucker. 2019. Cooling cows with sprinklers: Effects of soaker flow rate and timing on behavioral and physiological responses to heat load and production. J. Dairy Sci. 102:528-538. https://doi.org/10.3168/jds.2018-14962.

Tucker, C. B., N. R. Cox, D. M. Weary, and M. Špinka. 2009a. Laterality of lying behaviour in dairy cattle. Appl. Anim. Behav. Sci. 120:125-131. https://doi.org/10.1016/j.applanim.2009.05.010.

Tucker, C. B., D. E. Dalley, J. L. K. Burke, and D. A. Clark. 2007a. Milking cows once daily influences behavior and udder firmness at peak and mid lactation. J. Dairy Sci. 90:1692-1703. https://doi .org/10.3168/jds.2006-577.

Tucker, C. B., S. J. Lacy-Hulbert, and J. R. Webster. 2009b. Effect of milking frequency and feeding level before and after dry off on dairy cattle behavior and udder characteristics. J. Dairy Sci. 92:3194-3203. https://doi.org/10.3168/jds.2008-1930.

Tucker, C. B., L. Munksgaard, E. M. Mintline, and M. B. Jensen. 2018. Use of a pneumatic push gate to measure dairy cattle motivation to lie down in a deep-bedded area. Appl. Anim. Behav. Sci. 201:15-24. https://doi.org/10.1016/j.applanim.2017.12.018.

Tucker, C. B., A. R. Rogers, and K. E. Schütz. 2008. Effect of solar radiation on dairy cattle behaviour, use of shade and body temperature in a pasture-based system. Appl. Anim. Behav. Sci. 109:141-154. https://doi.org/10.1016/j.applanim.2007.03.015.

Tucker, C. B., A. R. Rogers, G. A. Verkerk, P. E. Kendall, J. R. Webster, and L. R. Matthews. 2007b. Effects of shelter and body condition on the behaviour and physiology of dairy cattle in winter. Appl. Anim. Behav. Sci. 105:1-13. https://doi.org/10.1016/j applanim.2006.06.009.

Tucker, C. B., and D. M. Weary. 2004. Bedding on geotextile mattresses: How much is needed to improve cow comfort? J. Dairy Sci. 87:2889-2895. https://doi.org/10.3168/jds.S0022-0302(04)73419 -0 .

Tucker, C. B., D. M. Weary, A. M. de Passillé, B. Campbell, and J. Rushen. 2006. Flooring in front of the feed bunk affects feeding behavior and use of freestalls by dairy cows. J. Dairy Sci. 89:20652071. https://doi.org/10.3168/jds.S0022-0302(06)72274-3.

Tucker, C. B., D. M. Weary, and D. Fraser. 2003. Effects of three types of free-stall surfaces on preferences and stall usage by dairy cows. J. Dairy Sci. 86:521-529. https://doi.org/10.3168/jds.S0022 -0302(03)73630-3.

Tucker, C. B., D. M. Weary, and D. Fraser. 2004. Free-stall dimensions: Effects on preference and stall usage. J. Dairy Sci. 87:12081216. https://doi.org/10.3168/jds.S0022-0302(04)73271-3.

Tucker, C. B., D. M. Weary, M. A. G. von Keyserlingk, and K. A. Beauchemin. 2009c. Cow comfort in tie-stalls: Increased depth of shavings or straw bedding increases lying time. J. Dairy Sci. 92:2684-2690. https://doi.org/10.3168/jds.2008-1926.

Tuyttens, F. A. M. 2005. The importance of straw for pig and cattle welfare: A review. Appl. Anim. Behav. Sci. 92:261-282. https://doi .org/10.1016/j.applanim.2005.05.007.

Val-Laillet, D., V. Guesdon, M. A. G. von Keyserlingk, A. M. de Passillé, and J. Rushen. 2009. Allogrooming in cattle: Relationships between social preferences, feeding displacements and social dominance. Appl. Anim. Behav. Sci. 116:141-149. https://doi.org/10 .1016/j.applanim.2008.08.005.

Van Nuffel, A., I. Zwertvaegher, L. Pluym, S. Van Weyenberg, V. M. Thorup, M. Pastell, B. Sonck, and W. Saeys. 2015. Lameness detection in dairy cows: Part 1 . how to distinguish between non-lame and lame cows based on differences in locomotion or behavior. Animals (Basel) 5:838-860. https://doi.org/10.3390/ani5030387.
Vasseur, E., J. Rushen, D. B. Haley, and A. M. de Passillé. 2012. Sampling cows to assess lying time for on-farm animal welfare assessment. J. Dairy Sci. 95:4968-4977. https://doi.org/10.3168/ jds.2011-5176.

Veissier, I., A. Butterworth, B. Bock, and E. Roe. 2008. European approaches to ensure good animal welfare. Appl. Anim. Behav. Sci. 113:279-297. https://doi.org/10.1016/j.applanim.2008.01.008.

Villettaz Robichaud, M., J. Rushen, A. M. de Passillé, E. Vasseur, K. Orsel, and D. Pellerin. 2019. Associations between on-farm animal welfare indicators and productivity and profitability on Canadian dairies: I. On freestall farms. J. Dairy Sci. 102:4341-4351. https:// doi.org/10.3168/jds.2018-14817.

von Keyserlingk, M. A. G., A. Barrientos, K. Ito, E. Galo, and D. M. Weary. 2012. Benchmarking cow comfort on North American freestall dairies: Lameness, leg injuries, lying time, facility design, and management for high-producing Holstein dairy cows. J. Dairy Sci. 95:7399-7408. https://doi.org/10.3168/jds.2012-5807.

von Keyserlingk, M. A. G., N. P. Martin, E. Kebreab, K. F. Knowlton, R. J. Grant, M. Stephenson, C. J. Sniffen, J. P. Harner III, A. D. Wright, and S. I. Smith. 2013. Invited review: Sustainability of the US dairy industry. J. Dairy Sci. 96:5405-5425. https://doi.org/10 $.3168 /$ jds.2012-6354.

Wagner-Storch, A. M., R. W. Palmer, and D. W. Kammel. 2003. Factors affecting stall use for different freestall bases. J. Dairy Sci. 86:2253-2266. https://doi.org/10.3168/jds.S0022-0302(03)73816 -8 .

Wales, W. J., D. W. Dellow, and P. T. Doyle. 2000a. Protein supplementation of cows grazing limited amounts of paspalum (Paspalum dilatatum Poir.)-dominant irrigated pasture in mid lactation. Aust. J. Exp. Agric. 40:923-929. https://doi.org/10.1071/EA00020.

Wales, W. J., D. W. Dellow, P. T. Doyle, and A. R. Egan. 2000b. Effects of feeding additional pasture hay in autumn to dairy cows grazing irrigated perennial ryegrass-white clover pasture and supplemented with barley grain. Aust. J. Exp. Agric. 40:1-9. https:// doi.org/10.1071/EA99109.

Walker, S. L., R. F. Smith, J. E. Routly, D. N. Jones, M. J. Morris, and H. Dobson. 2008. Lameness, activity time-budgets, and estrus expression in dairy cattle. J. Dairy Sci. 91:4552-4559. https://doi .org $/ 10.3168 /$ jds. 2008-1048.

Wang, F. X., D. F. Shao, S. L. Li, Y. J. Wang, A. Azarfar, and Z. J. Cao. 2016. Effects of stocking density on behavior, productivity, and comfort indices of lactating dairy cows. J. Dairy Sci. 99:37093717. https://doi.org/10.3168/jds.2015-10098.

Watters, M. E. A., K. M. A. Meijer, H. W. Barkema, K. E. Leslie, M. A. G. von Keyserlingk, and T. J. DeVries. 2013. Associations of herd- and cow-level factors, cow lying behavior, and risk of elevated somatic cell count in free-stall housed lactating dairy cows. Prev. Vet. Med. 111:245-255. https://doi.org/10.1016/j.prevetmed .2013.05.015.

Webster, J. R., M. Stewart, A. R. Rogers, and G. A. Verkerk. 2008. Assessment of welfare from physiological and behavioural responses of New Zealand dairy cows exposed to cold and wet conditions. Anim. Welf. 17:19-26.

Wechsler, B., J. Schaub, K. Friedli, and R. Hauser. 2000. Behaviour and leg injuries in dairy cows kept in cubicle systems with straw bedding or soft lying mats. Appl. Anim. Behav. Sci. 69:189-197. https://doi.org/10.1016/S0168-1591(00)00134-9.

Weigele, H. C., L. Gygax, A. Steiner, B. Wechsler, and J. B. Burla. 2018. Moderate lameness leads to marked behavioral changes in dairy cows. J. Dairy Sci. 101:2370-2382. https://doi.org/10.3168/ jds.2017-13120.

Westin, R., A. Vaughan, A. M. de Passillé, T. J. DeVries, E. A. Pajor, D. Pellerin, J. M. Siegford, E. Vasseur, and J. Rushen. 2016. Lying times of lactating cows on dairy farms with automatic milking systems and the relation to lameness, leg lesions, and body condition score. J. Dairy Sci. 99:551-561. https://doi.org/10.3168/jds .2015-9737.

Winckler, C., C. B. Tucker, and D. M. Weary. 2015. Effects of underand overstocking freestalls on dairy cattle behaviour. Appl. Anim. Behav. Sci. 170:14-19. https://doi.org/10.1016/j.applanim.2015.06 .003 . 
Yeiser, E. E., K. E. Leslie, M. L. McGilliard, and C. S. PeterssonWolfe. 2012. The effects of experimentally induced Escherichia coli mastitis and flunixin meglumine administration on activity measures, feed intake, and milk parameters. J. Dairy Sci. 95:49394949. https://doi.org/10.3168/jds.2011-5064.

Yunta, C., I. Guasch, and A. Bach. 2012. Short communication: Lying behavior of lactating dairy cows is influenced by lameness especially around feeding time. J. Dairy Sci. 95:6546-6549. https://doi .org/10.3168/jds.2012-5670.

Zähner, M., L. Schrader, R. Hauser, M. Keck, W. Langhans, and B. Wechsler. 2004. The influence of climatic conditions on physiological and behavioural parameters in dairy cows kept in open stables. Anim. Sci. 78:139-147. https://doi.org/10.1017/ S1357729800053923.

Zambelis, A., M. Gagnon-Barbin, J. St John, and E. Vasseur. 2019. Development of scoring systems for abnormal rising and lying down by dairy cattle, and their relationship with other welfare outcome measures. Appl. Anim. Behav. Sci. 220:104858. https:// doi.org/10.1016/j.applanim.2019.104858.
Zimov, J. L., N. A. Botheras, W. P. Weiss, and J. S. Hogan. 2011. Associations among behavioral and acute physiologic responses to lipopolysaccharide-induced clinical mastitis in lactating dairy cows. Am. J. Vet. Res. 72:620-627. https://doi.org/10.2460/ajvr .72.5.620.

Zobel, G., D. M. Weary, K. E. Leslie, and M. A. G. von Keyserlingk. 2015. Invited review: Cessation of lactation: Effects on animal welfare. J. Dairy Sci. 98:8263-8277. https://doi.org/10.3168/jds.2015 $-9617$.

\section{ORCIDS}

Cassandra B. Tucker @ (ㄴ https://orcid.org/0000-0002-6014-444X

Margit Bak Jensen (i) https://orcid.org/0000-0001-7982-582X

Laura Hänninen @ https://orcid.org/0000-0001-5118-8451

Jeffrey Rushen $\odot$ https://orcid.org/0000-0003-1951-5250 